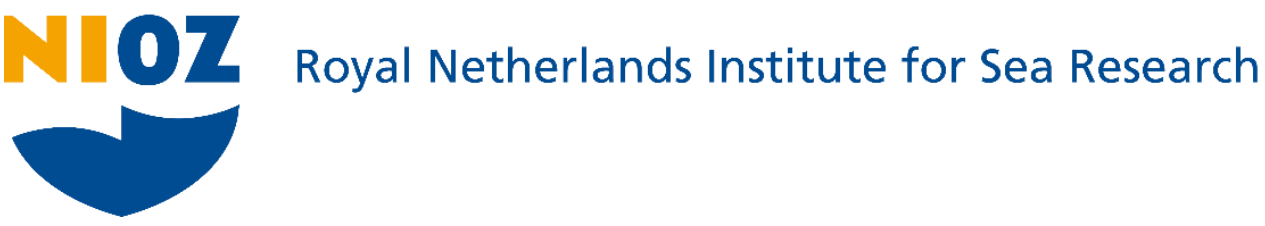

This is a postprint of:

Jung, A.S.; Brinkman, A.G.; Folmer, E.O.; Herman, P.M.J.; van der Veer, H.W. \& Philippart, C.J.M. (2017). Long-term trends in nutrient budgets of the western Dutch Wadden Sea (19762012). Journal of Sea Research, 127, 82-94

Published version: https://dx.doi.org/10.1016/..seares.2017.02.007

Link NIOZ Repository: www.vliz.be/imis?module=ref\&refid=289127

[Article begins on next page]

The NIOZ Repository gives free access to the digital collection of the work of the Royal Netherlands Institute for Sea Research. This archive is managed according to the principles of the Open Access Movement, and the Open Archive Initiative. Each publication should be cited to its original source - please use the reference as presented.

When using parts of, or whole publications in your own work, permission from the author(s) or copyright holder(s) is always needed. 


\section{Long-term trends in nutrient budgets of the western Dutch Wadden Sea}

\section{$2 \quad(1976-2012)$}

3 A.S. Jung ${ }^{1, *}$, A.G. Brinkman², E.O. Folmer ${ }^{1}$, P.M.J. Herman ${ }^{3}$, H.W. van der Veer ${ }^{1}$, C.J.M. Philippart ${ }^{1,4}$

$4 \quad{ }^{1}$ NIOZ Royal Netherlands Institute for Sea Research, Department of Coastal Systems, and Utrecht 5 University, P.O. Box 59, 1790 AB Den Burg, Texel, The Netherlands

$6 \quad{ }^{2}$ Wageningen Marine Research, P.O. Box 57, 1780 AB Den Helder, The Netherlands

$7 \quad{ }^{3}$ Deltares, P.O. Box 177, 2600 MH Delft, The Netherlands

$8{ }^{4}$ University of Utrecht, Department of Physical Geography, P.O. Box 80.115, 3508 TC Utrecht, The

9 Netherlands

${ }^{*}$ Corresponding author, e-mail: sarina.jung@nioz.nl

ABSTRACT

Long-term field observations of nitrogen $[\mathrm{N}]$ and phosphorus $[\mathrm{P}]$ concentrations were used to construct nutrient budgets for the western Dutch Wadden Sea between 1976 and 2012. Nutrients come into the western Dutch Wadden Sea via river runoff, through exchange with the coastal zone of the North Sea, neighbouring tidal basins and through atmospheric deposition (for $\mathrm{N}$ ). The highest concentrations in phosphorus and nitrogen were observed in the mid-1980s. Improved phosphorus removal at waste water treatment plants, management of fertilization in agriculture and removal of phosphates from detergents led to reduced riverine nutrient inputs and, consequently, reduced nutrient concentrations in the Wadden Sea. The budgets suggest that the period of the initial net import of phosphorus and nitrogen switched to a net export in 1981 for nitrogen and in 1992 for phosphorus. Such different behaviour in nutrient budgets during the rise and fall of external nutrient concentrations may be the result of different sediment-water exchange dynamics for $\mathrm{P}$ and $\mathrm{N}$. It is hypothesized that during the period of increasing eutrophication (1976-1981) P, and to a lesser degree $\mathrm{N}$, were stored in sediments as organic and inorganic nutrients. In the following period (1981-1992) external nutrient concentrations (especially in the North Sea) decreased, but P concentrations in the Wadden Sea remained high due to prolonged sediment release, while denitrification removed substantial amounts of $\mathrm{N}$.

From 1992 onwards, $\mathrm{P}$ and $\mathrm{N}$ budgets were closed by net loss, most probably because $\mathrm{P}$ stores were then depleted and denitrification continued. Under the present conditions (lower rates of sediment 
import and depleted P stores), nutrient concentrations in this area are expected to be more strongly influenced by wind-driven exchange with the North Sea and precipitation-driven discharge from Lake IJssel. This implies that the consequences of climate change will be more important, than during the 1970s and 1980s.

\section{HIGHLIGHTS}

- The main sources and sinks of phosphorus and nitrogen were different before, during and after the eutrophication peak in the mid-1980s

\section{- Eutrophication of North Sea advanced that of the Wadden Sea}

- Nutrient imports from river runoff either directly via Lake IJssel or indirectly via the coastal zone of the North Sea are the main sources

- $\mathrm{P}$ budget indicates a long-term (ca. 10 years) storage and release of $\mathrm{P}$ from the sediment

- Nutrient reduction did not (yet) results in conditions as found before eutrophication

\section{KEYWORDS}

Wadden Sea, Coastal North Sea, Nutrient exchange, Nitrogen, Phosphorus, Eutrophication, Nutrient budgets

\section{INTRODUCTION}

Estuaries are highly productive ecosystems, mainly because they receive large inputs of nutrients and organic matter from both river runoff and the open sea (Cloern et al., 2013; Nixon, 1995). Since the 1960s, there has been much environmental concern about the effects of increased riverine nutrient supply on the structure and functioning of estuarine ecosystems in Europe (Rosenberg, 1985) and the United States (Cloern et al., 2013). Particularly, increased inputs of nutrients had major consequences for the coastal ecosystems, such as an increase of biomass of primary producers leading to oxygen depletion, changing species compositions and biodiversity and shifts to bloom-forming algae species, some of which are toxic (e.g. Cloern, 2001). Eutrophication is, amongst others, referred to as the excessive increase in nutrient inputs (Golterman, 1975) and the increase of organic matter due to an increased nutrient supply (). Here, we use the first definition. Worldwide measures in the 1980s following conventions, legislative instruments and other laws on eutrophication (Ferreira et al., 2011) were successful in reducing nutrient loads in the North Sea and Baltic Sea, but less effective in other European and US coastal waters, in particular for nitrogen (Grizzetti et al., 2012; Scavia and Bricker, 2006). 
The Wadden Sea, located in the south-eastern part of the North Sea bordering Denmark, Germany and The Netherlands is a shallow, intertidal sea consisting of intertidal flats, shallow subtidal flats, drainage gullies and deeper inlets and channels. Due to its outstanding universal values, it became a UNESCO world heritage site in 2009 (www.waddensea-worldheritage.org). The western part of the Dutch Wadden Sea is a highly dynamic estuarine environment with nutrient inputs from two main sources, i.e. from Lake IJssel, receiving water from the river Rhine, and from the coastal waters of the North Sea connected to the tidal basins via tidal inlets between the barrier islands (DuranMatute et al., 2014; Postma, 1950; Ridderinkhof et al., 1990). Field measurements and information from reflectance images retrieved by means of remote sensing suggest the presence of a coastal zone seaward of the barrier islands in which such an exchange of water, nutrients and organic matter between the Wadden Sea and the North Sea takes place (Jung et al., 2016; Postma, 1981; Postma, 1984; van Raaphorst et al., 1998; Visser et al., 1991).

Loadings of nitrogen and phosphorus into the coastal waters of the North Sea, including the western Wadden Sea, strongly increased from the early 1950s until the early 1980s and decreased since the mid-1980s (e.g. Philippart et al., 2007; Prins et al., 2012; van Raaphorst and de Jonge, 2004; van Raaphorst et al., 2000; Vermaat et al., 2008). Between 1978 and 1987, the main nutrient source in the western Wadden Sea was Lake IJssel (approximately 50\% for phosphorus and 75\% for nitrogen; Philippart et al., 2000). Consequently, during the early 1980s, the relative contribution of loading from the coastal North Sea was low; the loading of phosphorus was less than $25 \%$ and that of nitrogen less than 5\% of the total loading (Philippart et al., 2000; van Raaphorst and van der Veer, 1990). Reduction of nutrients that started in the late 1970 s was uneven in that $P$ loadings were more effectively reduced than $\mathrm{N}$ loadings. This led to a large imbalance in the $\mathrm{N}: \mathrm{P}$ stoichiometry in the Wadden Sea (Philippart et al., 2007) and the North Sea (Burson et al., 2016) and has affected the phytoplankton communities and productivity (Burson et al., 2016; Philippart et al., 2007). In particular during the spring bloom, phytoplankton in general is now mainly P-limited, whereas a SiP-co-limitation is likely for the diatom populations, when present (Ly et al., 2014).

Nutrient dynamics are not only influenced by the loadings of dissolved phosphorus and nitrogen, but also by sedimentary processes (storage, burial, remineralization, and denitrification) and sedimentwater exchange of their particulate and dissolved forms. A recent study on sediment budgets showed that sedimentation rates in the western Wadden Sea are under the long-term influence of the closure of the southern part of the former Zuiderzee in 1932 (Elias et al., 2012). The closure has formed the present Lake IJssel and has resulted in an increased net inward transport of sediment and its associated organic matter, as tidal channels had to adjust to lower tidal volumes. Apart from 
these long-term morphological adjustments, sedimentary processes also interact with eutrophication trends. At the onset of eutrophication, local phosphorus concentrations might be buffered by net storage of $\mathrm{P}$ in the sediment, followed by gradual release after reduction of nutrient loads (Prastka et al., 1998). In the western Wadden Sea, remineralization plays an important role in the P cycle (Leote et al., 2015). Here, phosphorus might be stored over a longer time in the sediment and therefore serve as a buffer between the freshwater source of Lake IJssel and the North Sea (Kuipers and van Noort, 2008; Tappin, 2002). Local nitrogen concentrations will be influenced by denitrification, i.e. the reduction of nitrate to dinitrogen gas. Because denitrification rates in coastal sediments are related to the amount and quality of sedimentary organic matter and the concentrations of nitrate in waters overlying the sediment, changes in loads of sediments, organic matter and nutrients influence the magnitude of this flux (Deek et al., 2012).

In this study, we present phosphorus and nitrogen budgets of the western Dutch Wadden Sea for the period 1976-2012 to analyse changes in the relative importance of import of nutrients from the North Sea coastal zone compared to that of other sources (Philippart et al., 2000; van Raaphorst and van der Veer, 1990). Previous budgets assumed that closing residuals of the budgets were related to the import of organic matter (N, P) and denitrification $(\mathrm{N})$. For the present budgets, the possible contribution of changes in sedimentation and pelagic-benthic fluxes to the closing residuals of the budgets are also considered.

\section{MATERIALS AND METHODS}

\subsection{Study area}

The Wadden Sea is a seaward barrier of sandy islands and shoals, stretching for $600 \mathrm{~km}$ from Denmark in the northeast to The Netherlands in the southwest. In this study, we focus on the Marsdiep and Vlie tidal basin in the westernmost part of the Dutch Wadden Sea. These basins are connected to the North Sea by two tidal inlets, i.e. the Marsdiep and the Vlie (Fig. 1A). Marsdiep and Vlie are the tidal basins with the main tidal inlets of the western Dutch Wadden Sea with tidal prisms of about $1050 \times 10^{6}$ and $1070-1150 \times 10^{6} \mathrm{~m}^{3}$, respectively (Duran-Matute et al., 2014; Philippart, M., 1988; Postma, 1982). The smaller Eierlandse Gat, located north of the Marsdiep and south-west of the Vlie tidal basin, has a tidal prism of $160-200 \times 10^{6} \mathrm{~m}^{3}$ and its water exchange with the Marsdiep and Vlie basins is relatively low (Duran-Matute et al., 2014; Postma, 1982). It was, therefore, decided to exclude this basin from the nutrient budget analyses (c.f. Philippart et al., 2000). On average, the temperature of the Marsdiep tidal basin varies between $3^{\circ} \mathrm{C}$ in February and $18^{\circ} \mathrm{C}$ in August (van Aken, 2008b). Freshwater enters the Marsdiep tidal basin directly from discharges of Lake IJssel and 
indirectly from river runoffs in the south via the coastal zone (Fig. 1A). The salinity shows high variability and depends strongly on the amount of fresh water entering the system (van Aken, 2008a).

\subsection{Nutrient data}

130 Time series on nutrient concentrations were obtained from the water quality monitoring database 131 (DONAR, http://www.watergegevens.rws.nl) of the Dutch Ministry of Transport and Public Works.

132 Details about the locations of the used stations and sampling methods can be found in Philippart et al., (2000) and van Raaphorst and van der Veer (1990). Total phosphorus (TP) includes dissolved inorganic phosphate (DIP), dissolved organic phosphorus (DOP) and particulate compounds of phosphorus (POP). Total nitrogen (TN) is the sum of ammonium $\left(\mathrm{NH}_{4}{ }^{+}\right)$, nitrate plus nitrite $\left(\mathrm{NO}_{\mathrm{x}}\right)$, dissolved organic nitrogen (DON) and particulate compounds of nitrogen (PON). For all stations which were used to construct the nutrient budgets (Fig. 1A), TP and TN concentrations were estimated from irregular measurements (see below) for every month from January 1976 to December $2012(n=444)$.

For Stations $b$ and $c$ (Fig. 1A), nutrient concentrations were measured during the full study period but sampling occurred at irregular intervals. To construct a regular data set with monthly values for all stations, generalized additive models (GAM) were fitted for nitrogen and phosphorus separately. We used GAM because of its ability to fit the non-linear seasonal and long-term trends.

The nutrient concentrations were modelled as a function of "Station" and as a function of the smoother $f_{1}$ for "Year" (for the long-term trend) and as a function of the smoother $f_{2}$ for "DaylnYear" (for the seasonal trend). To smooth the seasonal trend, a penalized cyclic cubic spline was used to ensure that the ends of the fitted seasonal splines match up. The statistical model for nutrient concentrations ([TP] and [TN]; mol $\mathrm{m}^{-3}$ ) at different stations (S), years (Y) and day in the year (D) reads:

Measurements at stations a, $d$ and e were, however, terminated in 1988 (a) and 1993 ( $d$ and e) (Fig. 1A). We estimated the nutrient concentrations at these locations by using measurements at other locations. We used the generated monthly values from the GAM (Eq. 1) for Station $f$ in Dutch coastal waters to obtain values for a, and of Station $\mathrm{g}$ in Lake IJssel for e and d. In both cases the relationships between the concentrations of the respective stations were obtained by fitting a linear model through the data where both stations were sampled on the same day in the following form: 
where Nut station $2_{2}$ is the nutrient concentration $\left(\mathrm{mol} \mathrm{m}^{-3}\right)$ at a station used for the nutrient budget calculations, i.e. Station a, e and d (Fig. 1B) and Nut $t_{\text {station } 1}$ is the measured nutrient concentration $\left(\mathrm{mol} \mathrm{m}^{-3}\right.$ ) at the reference stations (i.e. $\mathrm{f}, \mathrm{g}$ ). After estimating $\alpha$ and $\beta$, the regression model was used to predict missing values at stations a, e and $d$.

To calculate the budgets the ratio of particulate $\mathrm{N}$ and $\mathrm{P}$ is needed for the water outside of the Marsdiep tidal inlet and the water inside the Marsdiep tidal inlet. However, the Station a was not sampled for the full period. Therefore concentrations of particulate $\mathrm{P}$ and $\mathrm{N}$ were derived from concentrations at Station $\mathrm{f}$ in a comparable way (GAM, followed by GLM), as done for total nutrients at the other stations but then for this station only.

\subsection{Nutrient budgets}

The pelagic nutrient fluxes through the western Wadden Sea were based on a hydrodynamic model containing advective water transport and tidal exchange rates (Ridderinkhof et al., 1990); it implies that we assumed a constant water flow through the system (from an input at the Vlie basin to an output at the Marsdiep basin). The atmospheric nitrogen input was based on values estimated for the southern North Sea by Rendell et al. (1993).

In line with nutrient budget analyses by Philippart et al., (2000) and van Raaphorst and van der Veer (1990), mass flows of phosphorus and nitrogen $\left(\mathrm{mol} \mathrm{s}^{-1}\right)$ were calculated by multiplying (i) the net advective water transport rates $\left(\mathrm{m}^{3} \mathrm{~s}^{-1} ; \mathrm{Q}_{1}\right.$ and $\mathrm{Q}_{2}$ ) with corresponding nutrient concentrations ( $\mathrm{mol}$ $\mathrm{m}^{-3}$ ) at Station b ("Marsdiep Noord") and Station c ("Vliestroom") in the western Wadden Sea, and (ii) a tidal exchange rate $\left(\mathrm{K}_{1}\right.$ in $\mathrm{m}^{3} \mathrm{~s}^{-1}$; Tab. 1$)$ with the difference in nutrient concentrations between Station b and Station a ("Callantsoog2"). Dispersive exchange between the North Sea and Vlie tidal basin was assumed to be very low, and therefore not considered separately (c.f. Philippart et al. 2000). Mass flows of phosphorus and nitrogen from Lake IJssel were determined by multiplying the daily averaged freshwater runoff $\left(\mathrm{m}^{3} \mathrm{~s}^{-1}\right)$ at the two discharge sluices Station $d$ ("Den Oever") in the west and Station e ("Kornwerderzand") in the east by their respective nutrient concentrations (mol $\mathrm{m}^{-3}$ ) (Fig. 1B; Table 1).

For phosphorus, each monthly budget was closed with a residual term labelled TP-flow ( $\mathrm{F}_{\mathrm{TP}, \text { residual; }}$ $\mathrm{mol} \mathrm{s}^{-1}$ ) which includes the accumulation of particulate matter originating from the open sea, a process described for the Wadden Sea (Postma, 1961) and several other coastal areas (Postma, 1980). For nitrogen, a constant atmospheric import of $0.19 \mathrm{mmol} \mathrm{N} \mathrm{m}{ }^{-2} \mathrm{day}^{-1}$ was assumed (Rendell 
et al., 1993). Residual flow rates of particulate nitrogen $\left(\mathrm{F}_{\mathrm{TN}, \text { residual } 1} ; \mathrm{mol} \mathrm{s}^{-1}\right)$ coinciding with $\mathrm{P}$ $\left(\mathrm{F}_{\mathrm{TP} \text {,residual; }} \mathrm{mol} \mathrm{s}^{-1}\right)$ were calculated from the particular phosphorus flows using ambient ratios of particulate nutrients $\left(\mathrm{N}: \mathrm{P}_{\text {particular; }} \mathrm{mol} \mathrm{mol}^{-1}\right)$ according to:

$\mathrm{F}_{\mathrm{TN}, \text { residual1 }}=\mathrm{N}: \mathrm{P}_{\text {particular }} \times \mathrm{F}_{\mathrm{TP}, \text { residual }}(1)$

Following Philippart et al. (2000), the ambient N : P-ratio of the particulate nutrients was computed on the basis of data from Station b. Finally, the nitrogen budget was closed with an additional and Nspecific residual flow $\left(\mathrm{F}_{\mathrm{TN}}\right.$,residual $\left.2 ; \mathrm{mol} \mathrm{s}^{-1}\right)$. The closing term of $\mathrm{P}$, and the first closing term of $\mathrm{N}$, account for storage and release of nutrients by sediments or microalgae, burial of organic matter in the sediment, unaccounted import from diffuse freshwater sources, and possibly other minor fluxes. The second closing term of $\mathrm{N}$ accounts mainly for denitrification, and further for deviations from standard stoichiometry in the fluxes covered by the first residual and for inorganic $P$ burial that is not stoichiometrically related to $\mathrm{N}$ burial. Inevitably, estimation errors in the other terms of the budget will also appear in the closing terms.

\subsection{Sedimentation}

Estimates of the contribution of sedimentation to the residuals of phosphorus $\left(\mathrm{F}_{\mathrm{TP}, \text { residual; }} \mathrm{mol} \mathrm{s}^{-1}\right)$ and nitrogen $\left(\mathrm{F}_{\mathrm{TN} \text {,residual; }} \mathrm{mol} \mathrm{s}^{-1}\right)$ were derived from sedimentation and erosion values for 5 -year periods of the Marsdiep and Vlie tidal basins $\left(\mathrm{m}^{3} \mathrm{y}^{-1}\right)$ as supplied by Elias et al. (2012). After conversion to average sedimentation and erosion rates for the western Dutch Wadden Sea, the sedimentation and erosion rates $\left(\mathrm{mm} \mathrm{y}^{-1}\right)$ were multiplied with the average phosphorus content of sandy and silty sediments, i.e. 100 and $225 \mu \mathrm{mol} \mathrm{P} \mathrm{g}{ }^{-1}$ dry sediment, respectively (Postma, 1954; van Raaphorst and Kloosterhuis, 1994).

\subsection{Burial, storage and release of nutrients by the sediment}

No long-term information on storage and release of nutrients by sediments existed. Therefore we constructed a storage and release time series based on the following assumptions. Storage of phosphorus in each year of the study period was estimated by assuming that around $30 \%$ of the TP input from the main freshwater source (Lake IJssel) got buried in the sediment after the spring bloom (Nixon et al., 1996). Release of P from the sediment in autumn varies between 10 and $40 \%$ of the stored P (Leote et al., 2015), and is inversely related to P concentrations in the water (Hupfer and Lewandowski, 2008). For this study, it was assumed that storage and release were equal during the first year (1976), implying that the maximum release of $P$ is $16.6 \%$ of the stored $P$ in the 
sediment. This rate was derived as follows. A P concentration of $0.066 \mathrm{~mol} \mathrm{P} \mathrm{m}^{-2}$ in the top $1 \mathrm{~cm}$ of the sediment as measured in the 1950 s by Postma (1954) was taken as a starting point $\left(\mathrm{P}_{0} ; \mathrm{mol} \mathrm{m}^{-2}\right)$ for construction of the sediment storage and release time series, as this is the only reliable source for $P$ in the sediment and an estimation of the change that happened in that time was out of the scope of this paper. For example, during the first year (1976) the annual burial was calculated as $30 \%$ of the total riverine $\mathrm{P}$ loads of $0.042 \mathrm{~mol} \mathrm{P} \mathrm{m}^{-2} \mathrm{y}^{-1}$ resulting in a burial of $0.013 \mathrm{~mol} \mathrm{P} \mathrm{m}^{-2} \mathrm{y}^{-1}$. Taking the assumed background value $\left(0.066 \mathrm{~mol} \mathrm{P} \mathrm{m}^{-2}\right)$ into consideration, this would add up to $0.066+$ $0.013=0.079 \mathrm{~mol} \mathrm{P} \mathrm{m}^{-2}$ after burial. The release in autumn would then be $16 \%$ of the stored $\mathrm{P}$ (i.e. $0.013 \mathrm{~mol} \mathrm{P} \mathrm{m}^{-2}$ ) leaving $0.066 \mathrm{~mol} \mathrm{P} \mathrm{m}^{-2}$ in the sediment in winter. Within the year 1976, the net change in $\mathrm{P}$ in the sediment was by definition kept in balance and would equal to zero.

\section{RESULTS}

\subsection{Model results and validation}

Predictions for missing values with GAM models were validated by searching for patterns in the residuals, but no such patterns could be detected (not shown). Predicted values using the GAM models were in line with observations at the different stations (Supplementary information 1 to 3 ). The GAM models were therefore used within this study.

\subsection{Nutrient budgets}

\subsubsection{Phosphorus}

The input of TP from Lake IJssel to the western Wadden Sea (i.e. Marsdiep and Vlie tidal basin) showed strong seasonality ranging between $0.0 \mathrm{mmol} \mathrm{P} \mathrm{m}^{-2} \mathrm{~d}^{-1}$ in summer and $0.6 \mathrm{mmol} \mathrm{P} \mathrm{m}^{-2} \mathrm{~d}^{-1}$ in winter (Fig. 2A). The input of TP from the North Sea into the Vlie tidal basin was positive by definition (as it is an advective flux with net inflow) and showed minor seasonality of less than 0.01 $\mathrm{mmol} \mathrm{P} \mathrm{m}^{-2} \mathrm{~d}^{-1}$ between relatively high inputs in winter and relatively low inputs in summer and autumn (Fig. 2B). At Marsdiep, the advective transport of $\mathrm{P}$ showed some seasonality with net export of more than $0.5 \mathrm{mmol} \mathrm{P} \mathrm{m}^{-2} \mathrm{~d}^{-1}$ in January in the early years and of less than $0.1 \mathrm{mmol} \mathrm{P} \mathrm{m^{-2 }}$ $\mathrm{d}^{-1}$ in June from 1995 (Fig. 2C). The tidally-driven exchange of nutrients between the Marsdiep tidal inlet and the North Sea was generally positive in January (ca. $0.5 \mathrm{mmol} \mathrm{P} \mathrm{m}^{-2} \mathrm{~d}^{-1}$ ), February (ca. 0.1

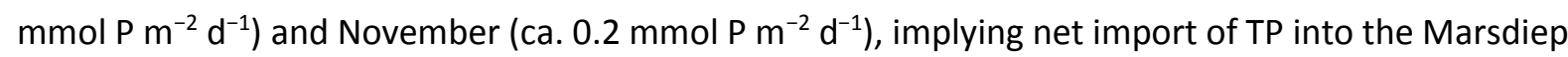
during these months, and negative and therefore net exporting $\mathrm{P}$ from the Marsdiep during the rest of the year; June is exceptional with high export rates (ca. $0.4 \mathrm{mmol} \mathrm{P} \mathrm{m}^{-2} \mathrm{~d}^{-1} ; \mathrm{Fig}$. 2D). The residual P load was generally negative in November, January and February, implying a net export up to 0.5

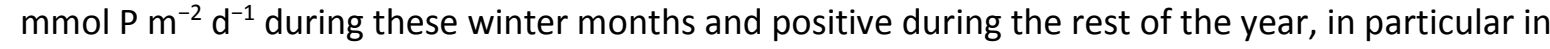
June, with a net import of more than $0.3 \mathrm{mmol} \mathrm{P} \mathrm{m}^{-2} \mathrm{~d}^{-1}$ (Fig. 2E). 
Figure $3 \mathrm{~A}$ presents the annual averages of the budget terms. The input of phosphorus from Lake

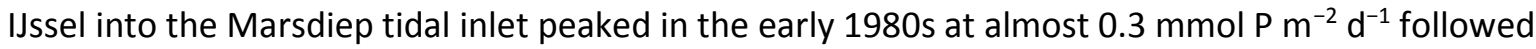
by a decrease until the early 2000s and stabilization hereafter at around $0.1 \mathrm{mmol} \mathrm{P} \mathrm{m}^{-2} \mathrm{~d}^{-1}$ (Fig. 3A). Between 1976 and 2012, the average positive loading from the North Sea to the Vlie tidal basin gradually declined from 0.17 to $0.06 \mathrm{mmol} \mathrm{P} \mathrm{m}^{-2} \mathrm{~d}^{-1}$ (Fig. 3B). The advective export from the Wadden Sea to the North Sea via Marsdiep declined from almost 0.4 in the 1980 s to less than 0.2 mmol P m$~^{-2} \mathrm{~d}^{-1}$ in the 2000s (Fig. 3C).The tidally driven export of phosphorus between the Wadden Sea and the North Sea generally declined during the study period and even became positive in 2011 and 2012, implying higher TP concentrations in the North Sea than in the Wadden Sea during these years (Fig. 3D). Between 1976 and 2012, the residual P-load changed from an annually averaged accumulation ( $>0.2 \mathrm{mmol} \mathrm{P} \mathrm{m}^{-2} \mathrm{~d}^{-1}$ in 1976) to a net loss since 1992 of almost $0.1 \mathrm{mmol} \mathrm{P} \mathrm{m}^{-2} \mathrm{~d}^{-1}$ in 2012 (Fig. 3E).

\subsubsection{Nitrogen}

The input of total nitrogen from Lake IJssel to the western Wadden Sea also showed a strong seasonality. It varied between $0 \mathrm{mmol} \mathrm{N} \mathrm{m} \mathrm{d}^{-1}$ in summer and $30 \mathrm{mmol} \mathrm{N} \mathrm{m}^{-2} \mathrm{~d}^{-1}$ in winter (Fig. 4A). Nitrogen input into the Vlie basin from the North Sea was always positive, with values ranging between more than $6 \mathrm{mmol} \mathrm{N} \mathrm{m}{ }^{-2} \mathrm{~d}^{-1}$ in late winter / early spring and $0.8 \mathrm{mmol} \mathrm{N} \mathrm{m}^{-2} \mathrm{~d}^{-1}$ in summer (Fig. 4B). The advective transport at the Marsdiep tidal inlet was always negative by definition with only minor seasonal signals whereas a minimum was reached in summer (less negative values, 1.5

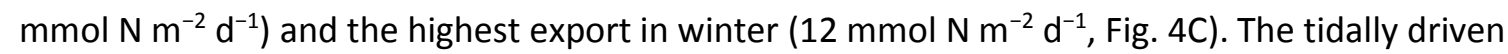
exchange between the western Wadden Sea and the North Sea was mostly negative (net export, around $5 \mathrm{mmol} \mathrm{N} \mathrm{m}{ }^{-2} \mathrm{~d}^{-1}$ and in spring even up to $15 \mathrm{mmol} \mathrm{N} \mathrm{m}^{-2} \mathrm{~d}^{-1}$ ), with net gain only in

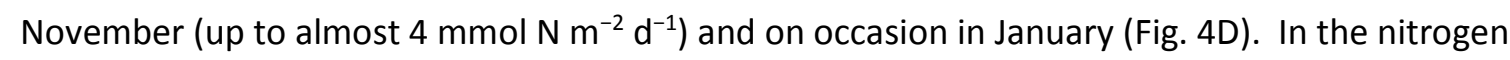
budget two residual terms were present. The first was estimated based on the phosphorus budget where the amount of exchange of phosphorus was assumed to be connected with a certain $\mathrm{N}: \mathrm{P}$ ratio to organic matter exchange with the North Sea. This residual of the nitrogen budget therefore followed the same pattern as in the phosphorus budget. Highest values were found in summer, with

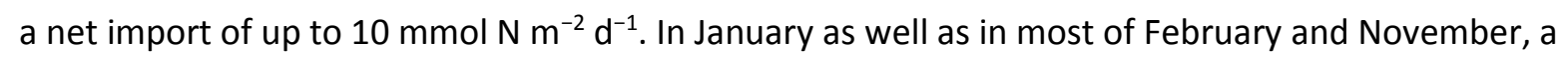
net export up to $15 \mathrm{mmol} \mathrm{N} \mathrm{m}^{-2} \mathrm{~d}^{-1}$ was found (Fig. 4E). The second residual in the nitrogen budget represented the closing term and showed a less clear seasonality than the other components of the nitrogen budget (Fig. 4F).

The annual averages of the nitrogen budget showed that the input into the western Wadden Sea from Lake IJssel peaked in the late 1980's $\left(12.5 \mathrm{mmol} \mathrm{N} \mathrm{m}^{-2} \mathrm{~d}^{-1}\right)$ with some variation in the 1990's (between 12 and $7 \mathrm{mmol} \mathrm{N} \mathrm{m}^{-2} \mathrm{~d}^{-1}$ ) and a relatively stable period after 1995 with an average 7.6 
mmol N m$~_{-2} \mathrm{~d}^{-1}$ (Fig. 5A). The exchange between the North Sea and the Vlie basin was always a net gain but it decreased over time from about $5 \mathrm{mmol} \mathrm{N} \mathrm{m}^{-2} \mathrm{~d}^{-1}$ to $1.5 \mathrm{mmol} \mathrm{N} \mathrm{m}^{-2} \mathrm{~d}^{-1}$ in the mid 1980 's and stayed constant since then (Fig. 5B). The advective transport at the Marsdiep inlet was always negative by definition, indicating a net export around 1975 with less variability over time but still a slight decrease from $7.8 \mathrm{mmol} \mathrm{N} \mathrm{m}^{-2} \mathrm{~d}^{-1}$ to $3.5 \mathrm{mmol} \mathrm{N} \mathrm{m}^{-2} \mathrm{~d}^{-1}$ in 2012 (Fig. 5C). For the tidally driven exchange with the North Sea a net export decreasing over time from almost $12 \mathrm{mmol} \mathrm{N} \mathrm{m}^{-2} \mathrm{~d}^{-1}$ around 1975 to around $2 \mathrm{mmol} \mathrm{N} \mathrm{m}{ }^{-2} \mathrm{~d}^{-1}$ in the mid 1980's and constant since then was found (Fig. 5D). Between 1976 and 2012, the exchange of nitrogen in the first residual changed from an annually averaged inward transport $\left(5 \mathrm{mmol} \mathrm{N} \mathrm{m}^{-2} \mathrm{~d}^{-1}\right.$ in 1976) to values around zero since 1980

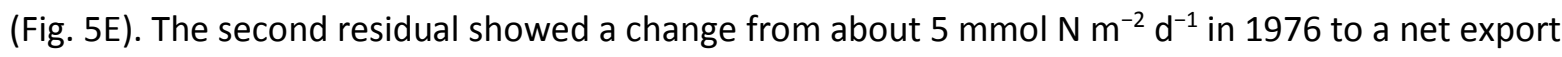
of nitrogen since 1980 with a maximum in 1988 of $7.5 \mathrm{mmol} \mathrm{N} \mathrm{m}^{-2} \mathrm{~d}^{-1}$ to a lesser value $(>2 \mathrm{mmol} \mathrm{N}$ $\mathrm{m}^{-2} \mathrm{~d}^{-1}$ ) in recent years (Fig. 5F).

\subsubsection{Residual vs freshwater import}

The influence of freshwater import versus exchange with the North Sea was analysed by a comparison of the import from Lake IJssel with the respective annual residuals of the two nutrients (Fig. 6). For phosphorus the residual was highest $\left(0.26 \mathrm{mmol} \mathrm{P} \mathrm{m}^{-2} \mathrm{~d}^{-1}\right)$ in 1976 and at the same time the import from Lake IJssel was small $\left(0.12 \mathrm{mmol} \mathrm{P} \mathrm{m}^{-2} \mathrm{~d}^{-1}\right)$ compared to later years (Fig. 6A). From 1976 to 1981 , the residuals of $\mathrm{P}$ continuously decreased to $0.04 \mathrm{mmol} \mathrm{P} \mathrm{m}^{-2} \mathrm{~d}^{-1}$ whilst the import of $P$ from Lake IJssel increased to $0.28 \mathrm{mmol} \mathrm{P} \mathrm{m}^{-2} \mathrm{~d}^{-1}$. From 1982 onwards, the residual of $\mathrm{P}$ started to be more variable but in general continued to decrease till the lowest value in this study $(-0.08 \mathrm{mmol}$ $\mathrm{P} \mathrm{m}^{-2} \mathrm{~d}^{-1}$ ) was reached in 2012. The import from Lake IJssel has decreased over time to relatively stable values between 0.1 and $0.2 \mathrm{mmol} \mathrm{P} \mathrm{m}^{-2} \mathrm{~d}^{-1}$ in the most recent years (Fig. 6A). These trends suggest two main phases, the first one (1976-1981) where the annual P residuals decreased and annual P imports from Lake IJssel increased, and the second one (1982-2012) were the P residuals decreased as did the P imports from Lake IJssel (Fig. 6A).

The pattern was similar for the first residual of the nitrogen budget with highest values for the residual at the start of the series in $1976\left(4.39 \mathrm{mmol} \mathrm{N} \mathrm{m}^{-2} \mathrm{~d}^{-1}\right)$ and relatively small values for the import from Lake IJssel $\left(4.8 \mathrm{mmol} \mathrm{N} \mathrm{m}^{-2} \mathrm{~d}^{-1}\right)$ followed by a period with decreasing residual and increasing import from Lake IJssel (Fig. 6B). In the nitrogen budget, the highest $\mathrm{N}$ import from Lake IJssel (12.4 mmol N m$~^{-2} \mathrm{~d}^{-1}$ ) occurred in 1988 (Fig. 6B). In that year, the $\mathrm{N}$ residual was $0.14 \mathrm{mmol} \mathrm{N}$ $\mathrm{m}^{-2} \mathrm{~d}^{-1}$. From 1989 onwards, the annual $\mathrm{N}$ residuals continued to decrease but less steeply and with occasional increases in between until a minimum was reached at the end of the study period in 2012 $\left(-1.29 \mathrm{mmol} \mathrm{N} \mathrm{m} \mathrm{m}^{-2} \mathrm{~d}^{-1}\right)$. At the same time the annual $\mathrm{N}$ imports from Lake IJssel decreased to values of less than $10 \mathrm{mmol} \mathrm{N} \mathrm{m}^{-2} \mathrm{~d}^{-1}$ with two exceptions in 1994 and 1995 and a minimum in 1996 with 5 
$\mathrm{mmol} \mathrm{N} \mathrm{m} \mathrm{d}^{-1}$. This suggests that the change in this relative behaviour within the annual $\mathrm{N}$ budgets occurred between 1988 and 1989 (Fig. 6B), which is seven years later than observed for P (i.e. between 1981 and 1982; Fig. 6A).

In the second residual of the nitrogen budget the trend was less pronounced than for the first $\mathrm{N}$ residual (Fig. 6C), but again this residual started in 1976 with the highest value (4.92 $\mathrm{mmol} \mathrm{N} \mathrm{m}^{-2} \mathrm{~d}^{-1}$ ) observed during the study period and reached its lowest value $\left(-7.40 \mathrm{mmol} \mathrm{N} \mathrm{m}^{-2} \mathrm{~d}^{-1}\right)$ in 1988 . From 1988 onwards, this second $\mathrm{N}$ residual varied between $-5.23 \mathrm{mmol} \mathrm{N} \mathrm{m}^{-2} \mathrm{~d}^{-1}(1994)$ and $-1.05 \mathrm{mmol} \mathrm{N}$ $\mathrm{m}^{-2} \mathrm{~d}^{-1}(1996)$. The behaviour of the second $\mathrm{N}$ residual in relation to the import of annual $\mathrm{N}$ from Lake IJssel suggests two phases, a period with a decreasing residual and an increasing import (19761988) followed by a period where relatively high residuals coincided with relatively low imports from Lake IJssel (Fig. 6C).

Comparing the trends in the closing residual of the $\mathrm{P}$ budget (Fig. 3E) and the total residual of the $\mathrm{N}$ budget (Fig. 5G) suggests three periods during the observational period, being (i) 1976-1980: where additional import of both phosphorus and nitrogen is required to close the respective $\mathrm{P}$ and $\mathrm{N}$ budgets, (ii) 1981-1991: where additional import of phosphorus is still needed to close the $\mathrm{P}$ budget, but additional export of $\mathrm{N}$ to close the $\mathrm{N}$ budget, and (iii) 1992-2012: where additional export of phosphorus and nitrogen is needed to close both nutrient budgets for the western Wadden Sea (Fig. 7).

\subsubsection{Sedimentation, erosion, storage and release}

The particle exchange between the North Sea and the western Wadden Sea (i.e. Marsdiep and Vlie tidal basin) changed from net sedimentation in the period before 2000 to net erosion hereafter (Elias et al., 2012). This means that also the net loading of particulate nutrients most probably switched from net import into the western Wadden Sea to net export to the North Sea. In case of phosphorus this changed from an import into the western Wadden Sea of around $0.03 \mathrm{mmol} \mathrm{P} \mathrm{m}^{-2}$ $\mathrm{d}^{-1}$ in the period 1975-1980 to an export of $0.01 \mathrm{mmol} \mathrm{P} \mathrm{m}^{-2} \mathrm{~d}^{-1}$ in the period 2000-2005 (Fig. 8). Assuming that the amount of stored phosphorus in the sediment had not changed between the early 1950s and the early 1970s, a net burial of $P$ in the sediment was found in the beginning of the study period in the early 1970s, followed by a period of net release of P since 1985, after which most years showed a net release with a maximum found in $1991\left(0.03 \mathrm{mmol} \mathrm{P} \mathrm{m}{ }^{-2} \mathrm{~d}^{-1}\right)$, which is 10 years after the highest import from Lake IJssel in 1981 (Fig. 8). After 1997, the net annual storage/release of P levelled out to around zero (Fig. 8).
4. DISCUSSION

4.1. Accuracy of model predictions for nutrient concentrations 
The analyses were computed partly using model estimates of nutrient concentrations based on measurements with a certain uncertainty. Model validations showed a good fit of all the models, giving an indication that at least the general direction of the budget should be trustworthy. However the fact that some of the model estimates are based on a combination of two different time series should be kept in mind. In addition, the relationships between nutrient concentrations of various stations used for estimating local nutrient concentrations when no data were available were assumed to be fixed in time, which might not have been true. So far there is no better alternative to this method. Import of nutrients in the western Dutch Wadden Sea from the freshwater can be direct (from Lake IJssel and other sources, (e.g. van Raaphorst and van der Veer, 1990)) and indirect (via the coast line of The Netherlands from the rivers, mainly the Rhine, e.g. de Jonge, 1990) in our study area. From these sources, only the freshwater import from Lake IJssel can be quantified as consistent long-term information since other freshwater nutrient sources are lacking. For 1950-1951, however, Postma (1954) estimated the import of total phosphorus from the canal "Noordhollands Kanaal" via the harbour of Den Helder into the Marsdiep to be $650 \mathrm{~kg}$ per tide $\left(0.03 \mathrm{mmol} \mathrm{P} \mathrm{m}^{-2} \mathrm{~d}^{-1}\right)$, i.e. in the same order of magnitude as the total P supplied via Lake IJssel (1,050 kg per tide, $\left.0.05 \mathrm{mmol} \mathrm{P} \mathrm{m}^{-2} \mathrm{~d}^{-1}\right)$. For 1985, van Meerendonk et al. (1988) estimated the import of total P from this canal into the Marsdiep to be 426 ton per year $\left(0.03 \mathrm{mmol} \mathrm{P} \mathrm{m}^{-2} \mathrm{~d}^{-1}\right.$ ), i.e. similar as in the early $1950 \mathrm{~s}$ ( $632 \mathrm{~kg}$ per tide or $0.02 \mathrm{mmol} \mathrm{P} \mathrm{m}^{-2} \mathrm{~d}^{-1}$ ) but now almost an order of magnitude lower than the total P supplied via Lake IJssel $\left(3,721\right.$ ton per year, $\left.0.23 \mathrm{mmol} \mathrm{P} \mathrm{m}^{-2} \mathrm{~d}^{-1}\right)$. For the year 1985 , the import of total $\mathrm{N}$ was estimated to be 1,837 ton per year $\left(0.25 \mathrm{mmol} \mathrm{N} \mathrm{m}^{-2} \mathrm{~d}^{-1}\right)$ from the canal and 59,725 ton per year (8.26 mmol N m$~_{-2} \mathrm{~d}^{-1}$ ) from Lake IJssel (van Meerendonk et al., 1988). Although the freshwater discharge from this canal is relatively low (i.e. $3 \%$ of the total freshwater discharges into the western Wadden Sea; van Meerendonk et al., 1988), its importance as an additional nutrient source cannot be excluded, in particular for $\mathrm{P}$ during the beginning of the study period before the maximum concentrations were reached in the mid-1980s.

Several compartments in our nutrient budget refer to the exchange of nutrients between North Sea and Wadden Sea as well as internal circulation (e.g. "Wadden Sea Throughput" and "Exchange North Sea") and they were calculated using a fixed coefficient. Recent models of the hydrodynamics of the western Wadden Sea revealed that these coefficients could be variable depending on wind velocity and direction that can be so strong as to even reverse the normal tidal flow (Duran-Matute et al., 2014) and lead to an average variability of the tidal prism of $20 \%$. So far, however, the outcomes of such hydrodynamic models are not available for the full study period of the nutrient budgets. 
Moreover, although variations in weather could explain some of the between-year variation, it is unlikely that they will explain the long-term changes discussed in this paper.

\subsection{Long-term trends}

389

390

391

392

393

394

395

396

397

398

399

400

401

402

403

404

405

406

407

408

409

410

411

412

413

414

415

416

417

Overall, there is a general increase of import of nutrients from Lake IJssel till the beginning of the 1980s and a subsequent reduction afterwards. Furthermore, the initial net gain of phosphorus and nitrogen in the system switched to net loss in the mid-1990s and the first residual of the nitrogen budget switched from positive (indicating an additional $\mathrm{N}$ gain) in the late 1970 s to negative (indicating net $\mathrm{N}$ loss) around 1980. There are several nutrient budgets available for the Wadden Sea, but often they only look at very short time spans (Grunwald et al., 2010) or were conducted before the 1990s (; ), when we detected a major change within our nutrient budgets.

Different behaviour in nutrients during nutrient increase and reduction, as were detected in this study, may be the result of changing boundary concentrations, temporary storage of nutrients in the sediment (as has been described for phosphorus) or enhanced denitrification (Cornwell et al., 1999; Kana et al., 1998; Nielsen et al., 1995).

In the 1970s freshwater runoff within Europe was highly loaded with nutrients and reached a peak in the early 1980s (van Raaphorst and de Jonge, 2004; van Raaphorst and van der Veer, 1990). Hereafter eutrophication was reduced and nutrient loads went down, also within the Wadden Sea (Grizzetti et al., 2012; Philippart and Cadée, 2000; Scavia and Bricker, 2006; van Raaphorst and van der Veer, 1990). This pattern is also clear in our study where the import from Lake IJssel into the western Wadden Sea peaked in 1981. However, our study period started in 1976 and is missing the early years in the eutrophication process that started in the 1960s (van Raaphorst and van der Veer, 1990), making it difficult to assess whether the observed changes are showing signs of the system going back to the original state as it has been before the eutrophication in the 1970 s or if it reached a new and different state of nutrient dynamics.

\section{High internal loadings from a large historical P-pool in sediments can delay recovery after $\mathrm{P}$} reduction for 10-15 years or longer in lakes (Jeppesen et al., 2005; Søndergaard et al., 2013) and has been proposed for estuaries as well (Prastka et al., 1998). Leote et al. (2015) stated that internal recycling might be the most important source for phosphorus in the system by the way of remineralization of stored material in the sediment, at least in recent years. Also van Beusekom and de Jonge (1998) suggested that part of the primary production in the Wadden Sea could only be sustained by this mechanism. We explored this possibility by estimating the stored and released $\mathrm{P}$ in 
the sediment and found a similarity with the order of magnitude and trend of the residual term of the $\mathrm{P}$ budget, indicating that this would at least be a possibility.

420 It is striking that the largest values of the residuals occur at the start of the study period, between 1976 and approximately 1984 for P (Fig. 3) and between 1976 and 1980 for N (Fig. 5G). The monotonic decrease of the P import at the Vlie tidal inlet during the full study period (Fig. 3B) indicates that the rise in P concentrations of the freshwater in Lake IJssel in the 1970s and 1980s is not reflected in the North Sea waters that enter through the Vlie during those years. This is pointing in the direction that the decrease in freshwater P sources for the North Sea coastal area has started earlier than the decrease in Lake IJssel concentrations (i.e. prior to 1976, whereas the decrease started in 1981 for Lake IJssel concentrations), which was also observed by de Jonge (1997). This would make sense, if one assumes that the same sediment burial and release mechanisms work in Lake IJssel as in the Wadden Sea. The advective exchange through the Marsdiep, in contrast (Fig. 3C), does reflect the initial rise in $\mathrm{P}$ concentrations in the western Wadden Sea, and the decrease from approximately 1983 onwards. However, the rise between 1976 and 1981 has been slower than the rise in input from Lake IJssel, in accordance with the hypothesis of internal storage within the western Wadden Sea and Lake IJssel. By far the largest contribution to the strongly positive residual of $P$ in the first years stems from the dispersive exchange in Marsdiep, showing that the concentration difference between western Wadden Sea and the North Sea in the surface water was much larger in 1976 than ten years later. If the $P$ residual reflects import of $P$, then there the concentration difference is directed towards the Wadden Sea, with higher concentrations in the North Sea than in the Wadden Sea in the mid-1970s, and smaller differences later on. This is in line with winter concentrations of phosphate in the river Rhine at the Dutch-German border, which peaked in the early 1970s, i.e. before the period covered by the nutrient budgets of this study (van Bennekom and Wetsteijn, 1990). This could mean that the effects of reduced nutrient import from the rivers could be observed earlier in the North Sea than in the Wadden Sea. Most likely this is caused by internal (storage) processes in Lake IJssel and in the western Wadden Sea that may have been stronger than in the North Sea, leading to lower concentrations in the 1970s, but eventually breaking down and releasing large amounts of $\mathrm{P}$ until the mid-1980s, even after the input of riverine input had been peaking. In particular, the enhanced release of $\mathrm{P}$ in anoxic sediment conditions, induced by enhanced organic carbon deposition, may have played a role in this process. It would be stronger in shallow systems such as Wadden Sea and Lake IJssel, than in the North Sea. Note, in this respect, that residual 2 of N, related to denitrification, has its strongest negative values during the mid-1980s. As denitrification is an anoxic process, this would naturally be accompanied by a relatively strong $\mathrm{P}$ release. 
452 For the nitrogen budget, the first residual was previously completely attributed to the import of

453 organic matter containing P and N (Philippart et al., 2000). Present findings on the phosphorus

454 budget now point, however, to additional process such as (i) import of dissolved nutrients and/or

455 organic matter from a canal near Den Helder at the beginning of the study period, (ii) long-term

456 variation in net sedimentation rates, and (iii) multi-annual storage and delayed release from the

457 sediment. In contrast to $P, N$ is not expected to have been stored and released over a multi-annual

458 period (Tappin, 2002). However, the influence of import by an additional freshwater source and role

459 of long-term changes in sedimentation rates on the $\mathrm{N}$ residual cannot be excluded. Due to

460 insufficient information on, for example, $N: P$ ratios of the freshwater discharge from the Den

461 Helder canal, we cannot estimate how large this fraction is.

462 The second and closing residual of the nitrogen budget was assumed to represent the atmospheric

463 part of the nitrogen cycle, i.e. denitrification, the reduction of nitrate to nitrogen-gas (Deek et al.,

464 2012; Gao et al., 2012; Philippart et al., 2000). For parts of the eastern Dutch and western German

465 Wadden Sea, Gao et al. (2012) estimated an annual loss of $745 \mathrm{mmol} \mathrm{N} \mathrm{m}^{-2} \mathrm{y}^{-1}$, corresponding to a

466 daily loss of $2.04 \mathrm{mmol} \mathrm{N} \mathrm{m}^{-2} \mathrm{~d}^{-1}$ which is in the range of what has been found by Deek et al. (2012) in

467 the northern German Wadden Sea $\left(2.1 \mathrm{mmol} \mathrm{N} \mathrm{m}^{-2} \mathrm{~d}^{-1}\right.$ close to Sylt and $3.8 \mathrm{mmol} \mathrm{N} \mathrm{m}^{-2} \mathrm{~d}^{-1}$ close to

468 Meldorf and the Elbe river) and in this study (average of $3.14 \mathrm{mmol} \mathrm{N} \mathrm{m}^{-2} \mathrm{~d}^{-1}$ in the period 1994-

469 2012, Table 2).

470 Comparison of the total residuals of $\mathrm{P}$ and $\mathrm{N}$ suggests that the western Wadden Sea was

471 characterized by three different periods within the study period with regard to the nutrient budgets.

472 During the first years (1976-1980), the budgets were closed by net gain of P and N, most probably as

473 the result of net import from the already nutrient-rich North Sea. From 1981 to 1991, the net gain of

474 P continued but the $\mathrm{N}$ budget was closed by a net loss, possibly as a result of net release from the

475 sediment for P and denitrification for N. From 1992, budgets were closed by a net loss of P and N,

476 possible because there was no longer a release of stored $\mathrm{P}$ and denitrification of $\mathrm{N}$ continued.

477 4.3. Future budgets

478 Several studies showed that wind and rainfall affect the hydrodynamics of the Wadden Sea

479 substantially (Donker, 2015; Duran-Matute et al., 2014; Duran-Matute \& Gerkema, 2015). Duran-

480 Matute et al. (2014) found how wind can change the advective transport. Both of these effects will

481 have an impact on the nutrient budgets since the exchange with the North Sea will be affected, as is

482 the exchange between basins, however these changes are mainly short term. There is no study so

483 far that analysed the changes in wind speed and direction over a long term perspective. Note,

484 however, that the main emphasis of this study is on the long multi-year time scale, and that the time

485 scale of wind-driven variability is much shorter than this. Unless it could be shown that wind patterns 
have systematically changed over the decades, and with that have changed the residual transport rates (which to our knowledge has never been proven), our estimates should be robust on longer time scales, even if there is wind-driven variability (besides variability from a multitude of other sources) in the short-term budget terms. An increased wind speed and bottom shear stress can also lead to an increased remineralization of phosphorus from the sediment due to increased disturbance (Leote et al., 2013). Rainfall may also affect the hydrodynamics, in direct and indirect ways. The direct way, being local rainfall, will have a minor effect on the nutrient concentration since maximum volume rates involved are at least two orders of a magnitude smaller than the tidal exchanges. However there are studies indicating that rainfall may influence the density gradient especially of flat areas and therefor is influencing the estuarine circulation and the respective exchange coefficient with the North Sea (Burchard et al., 2008). Indirect effects are larger, maximum fresh water discharge from Lake IJssel after periods with heavy rainfall may be up to $2000 \mathrm{~m}^{3} \mathrm{~s}^{-1}$ (RWS, 2015), which is almost the same as the regular residual advective transport of $3556 \mathrm{~m}^{3} \mathrm{~s}^{-1}$ through the tidal inlets. Not all tidal basins in the Wadden Sea have inflow of freshwater. It is not clear how the nutrient budgets of these tidal basins are and how they are affected by changing wind and rain conditions. A study by Grunwald et al. (2010) in the tidal basin behind the German Wadden Sea island Spiekeroog, with only limited fresh water influence indicates that in these tidal basins an export of inorganic material is taking place that is not outbalanced by organic material being imported in the case of phosphorus. In their budget the import of organic material into the basin is higher for nitrogen than the export estimated, however they do not take Ammonium into account when looking at the export of inorganic material. This makes it difficult to directly compare the results from our study with the results of Grunwald et al. (2010). There is an indication that also denitrification might be higher in sediments with a lager freshwater inflow (Deek et al., 2012), which would at least partly explain the differences between the model by Grunwald et al. (2010) and this study. The budgets of this study require extensive nutrient data. However, extensive data sets are rare and most of the tidal basins have not been investigated extensively over a long period. Recently developed hydrodynamical models such as the GETM model of the Wadden Sea (Duran-Matute et al., 2014) could help in revealing previous hydrodynamics and water budgets of all tidal basins and could help developing nutrient budgets also for other basins by predicting water flow and nutrient concentrations at stations not directly monitored (Tiessen et al., 2012). Such models also bear the potential to allow an estimate how future changes in climate, like increased rainfall and stronger

517 storms as projected by the Dutch Meteorological Institute (van den Hurk et al., 2006), may affect the nutrient budgets and subsequently primary production of the Wadden Sea. 
We are most grateful to Rijkswaterstaat for the start and continuation of the long-term monitoring program on nutrients in the North Sea and the Wadden Sea, and to all who were involved in sampling and analyses. We furthermore acknowledge the scientific interactions with our colleagues of the INFOWEB project, i.e. the NIOZ Netherlands Institute of Sea Research (Texel \& Yerseke, NL), the Alfred Wegener Institute for Polar and Marine Research (Sylt, D), Senckenberg Institute (Wilhelmshaven, D) and the University of Groningen (Groningen, NL). This research is performed within the framework of the "The impact of biological invasions on the food web of the Wadden Sea (INFOWEB)" project, as part of a bilateral Wadden Sea research program that is jointly funded by the German Federal Ministry of Education and Research (Bundesministerium für Bildung und Forschung; BMBF) and the Dutch NWO (Nederlandse Organisatie voor Wetenschappelijk Onderzoek) Earth and Life Sciences. 6. REFERENCES Burchard, H., Flöser, G., Staneva, J. V., Badewien, T. H., and Riethmüller, R. 2008. Impact of density gradients on net sediment transport into the Wadden Sea. J. Phys. Oceanogr., 38:566-587. http://dx.doi.org/10.1175/2007JPO3796.1 nutrient loads has created an offshore gradient from phosphorus to nitrogen limitation in the North Sea. Limnol. Oceanogr., 61:869-888. http://dx.doi.org/10.1002/Ino.10257

Cloern, J. E. 2001. Our evolving conceptual model of the coastal eutrophication problem. Mar. Ecol. Prog. Ser., 210:223-253. http://dx.doi.org/:10.3354/meps210223

Cloern, J. E., Foster, S. Q., and Kleckner, A. E. 2013. Review: phytoplankton primary production in the world's estuarine-coastal ecosystems. Biogeosci. Discuss., 10:17725-17783. http://dx.doi.org/10.5194/bgd-10-17725-2013 environmental controls, and ecosystem level controls, a review. Aqu. Ecol., 33:41-54. http://dx.doi.org/10.1023/A:1009921414151 the River Rhine. In: McLusky, D. S.; de Jonge, V. N. \& Pomfret, J. (Eds.) North Sea-Estuaries

548 Interactions: Proceedings of the 18th EBSA Symposium held in Newcastle upon Tyne, U.K., 29th

549 August to 2nd September, 1988, Springer Netherlands, 49-62. 
de Jonge, V. N. 1997. High remaining productivity in the Dutch western Wadden Sea despite decreasing nutrient inputs from riverine sources. Mar. Pollut. Bull., 34:427-436.

Deek, A., Emeis, K., and van Beusekom, J. E. E. 2012. Nitrogen removal in coastal sediments of the German Wadden Sea. Biogeochem., 108:467-483. http://dx.doi.org/10.1007/s10533-011-9611-1

Donker, J. J. A. 2015. Hydrodynamic processes and the stability of intertidal mussel beds in the Dutch Wadden Sea. Utrecht Studies in Earth Sciences, 1-134.

Duran-Matute, M., and Gerkema, T. 2015. Calculating residual flows through a multiple-inlet system: the conundrum of the tidal period. Ocean Dyn., 65, 1461-1475. http://dx.doi.org/10.1007/s10236$\underline{015-0875-1}$

Duran-Matute, M., Gerkema, T., De Boer, G. J., Nauw, J. J., and Gräwe, U. 2014. Residual circulation and freshwater transport in the Dutch Wadden Sea: a numerical modelling study. Ocean Sci., 10(4):611-632. http://dx.doi.org/10.5194/os-10-611-2014

Elias, E. P. L.; Van der Spek, A. J. F.; Wang, Z. B. \& De Ronde, J. 2012. Morphodynamic development and sediment budget of the Dutch Wadden Sea over the last century. Neth. J. Geosci., 91:293-310. http://dx.doi.org/10.1017/S0016774600000457

Ferreira, J. G., Andersen, J. H., Borja, A., Bricker, S. B., Camp, J., Cardoso da Silva, M., Garcés, E., Heiskanen, A.-S., Humborg, C., Ignatiades, L., Lancelotj, C., Menesguenk, A., Tettl, P., Hoepffnerm, N., Claussenn, U. 2011. Overview of eutrophication indicators to assess environmental status within the European Marine Strategy Framework Directive. Estuarine Coastal Shelf Sci., 93:117-131.

\section{http://dx.doi.org/10.1016/j.ecss.2011.03.014}

Gao, H., Matyka, M., Liu, B., Khalili, A., Kostka, J. E., Collins, G., Jansen, S., Holtappels, M., Jensen, M. M., Badewien, T. H., Beck, M., Grunwald, M., de Beer, D., Lavik, G., Kuypers, M.M.M. 2012. Intensive and extensive nitrogen loss from intertidal permeable sediments of the Wadden Sea. Limnol. Oceanogr., 57:185-198. http://dx.doi.org/10.4319/lo.2012.57.1.0185

Golterman, H.L. 1975.Physiological limnology: An approach to the physiology of lake ecosystems. Elsevier Scientific Publishing Co. New York. 489pp

Grizzetti, B., Bouraoui, F., and Aloe, A. 2012. Changes of nitrogen and phosphorus loads to European seas. Global Change Biol., 18(2):769-782. http://dx.doi.org/10.1111/j.1365-2486.2011.02576.x 
579 Grunwald, M., Dellwig, O., Kohlmeier, C., Kowalski, N., Beck, M., Badewien, T. H., Kotzur, S.,

580 Liebezeit, G., Brumsack, H.-J. 2010. Nutrient dynamics in a back barrier tidal basin of the Southern

581 North Sea: Time-series, model simulations, and budget estimates. J. Sea Res., 64:199-212.

582 http://dx.doi.org/10.1016/j.seares.2010.02.008

583

584

585

586

587

588

589

590

591

592

593

594

595

596

597

598

599

600

601

602

603

604

605

606

607

608

Hupfer, M. and Lewandowski, J. 2008. Oxygen controls the phosphorus release from Lake

Sediments-a long-lasting paradigm in limnology. Int. Rev. Hydrobiol., 93(4-5):415-432.

http://dx.doi.org/10.1002/iroh.200711054

Jeppesen, E., Søndergaard, M., Jensen, J. P., Havens, K. E., Anneville, O., Carvalho, L., Coveney, M. F., Deneke, R., Dokulil, M. T., Foy, B., Gerdeaux, D., Hampton, S. E., Hilt, S., Kangur, K., Köhler, J., Lammens, E. H.H.R., Lauridsen, T. L., Manca, M., Miracle, M. R., Moss, B., Nõges, P., Persson, G., Phillips, G., Portielje, R., Romo, S., Schelske, C. L., Straile, D., Tatrai, I., Willén, E., Winder, M. 2005. Lake responses to reduced nutrient loading-an analysis of contemporary long-term data from 35 case studies. Freshwater Biol., 50:1747-1771. http://dx.doi.org/10.1111/j.1365-2427.2005.01415.x

Jung, A. S., Bijkerk, R., van der Veer, H. W., and Philippart, C. J. M. 2016. Spatial and temporal trends in marine phytoplankton richness as a tracer for mixing between Wadden Sea and North Sea waters. J Mar Biol Ass., (in press). http://dx.doi.org/10.1017/S0025315416001326

Kana, T. M., Sullivan, M. B., Cornwell, J. C., and Groxzkowski, K. M. 1998. Denitrification in estuarine sediments determined by membrane inlet mass spectrometry. Limnol. Oceanogr., 43:334-339. http://dx.doi.org/10.4319/lo.1998.43.2.0334

Kuipers, B. R. and van Noort, G. J. 2008. Towards a natural Wadden Sea? J. Sea Res., 60:44-53. http://dx.doi.org/10.1016/i.seares.2008.04.002

Leote, C., Epping, E., and van Cappellen, P. 2013. Phosphate sorption from seawater solutions: Particle concentration effect. Mar. Chem., 148:52-62.

http://dx.doi.org/10.1016/j.marchem.2012.12.002

Leote, C., Mulder, L. L., Philippart, C. J. M., and Epping, E. H. G. 2015. Nutrients in the western Wadden Sea: Freshwater input versus internal recycling. Est Coasts, 39:1-14. http://dx.doi.org/10.1007/s12237-015-9979-6

Ly, J., Philippart, C. J. M., and Kromkamp, J. C. 2014. Phosphorus limitation during a phytoplankton spring bloom in the western Dutch Wadden Sea. J. Sea Res., 88:109-120.

http://dx.doi.org/10.1016/j.seares.2013.12.010 
Nielsen, K., Nielsen, L., and Rasmussen, P. 1995. Estuarine nitrogen retention independently

610 estimated by the denitrification rate and mass balance methods: a study of Norsminde Fjord, Denmark. Oceanogr. Lit. Rev., 11:958. http://dx.doi.org/10.3354/meps119275

Nixon, S. W. 1995. Coastal marine eutrophication: a definition, social causes, and future concerns. Ophelia, 41:199-219. http://dx.doi.org/10.1080/00785236.1995.10422044

614 Nixon, S. W., Ammerman, J. W., Atkinson, L. P., Berounsky, V. M., Billen, G., Boicourt, W., Boynton, 615 W. R., Church, T. M., Ditoro, D. M., Elmgren, R., Garber, J. H., Giblin, A. E., Jahnke, R. A., Owens, N. J. 616 P., Pilson, M. E. Q., Seitzinger, S. P. 1996. The fate of nitrogen and phosphorus at the land-sea margin of the North Atlantic Ocean. In Nitrogen cycling in the North Atlantic Ocean and its Watersheds, pages 141-180. Springer Verlag, New York. http://dx.doi.org/10.1007/BF02179826

Philippart, C. J. M., Beukema, J. J., Cadée, G. C., Dekker, R., Goedhart, P. W., van Iperen, J. M., Leopold, M. F., and Herman, P. M. J. 2007. Impacts of nutrient reduction on coastal communities. Ecosys, 10:95-118. http://dx.doi.org/10.1007/s10021-006-9006-7

Philippart, C. J. M. and Cadée, G. C. 2000. Was total primary production in the western Wadden Sea stimulated by nitrogen loading? Helgol. Mar. Res., 54:55-62.

Philippart, C. J. M., Cadée, G. C., van Raaphorst, W., and Riegman, R. 2000. Long-term phytoplankton-nutrient interactions in a shallow coastal sea: Algal community structure, nutrient budgets, and denitrification potential. Limnol. Oceanogr., 45:131-144.

http://dx.doi.org/10.4319//o.2000.45.1.0131

Philippart, M. 1988. Tijdschalen in de Waddenzee (Time scales in the Wadden Sea). Institute for Meteorology and Oceanography (IMOU), State University Utrecht, pages 1-51.

Postma, H. 1950. The distribution of temperature and salinity in the Wadden Sea. Tijdschrift van het Koninkijk Nederlandsch Aardrijkskundig Genootschap, 67:34-42.

Postma, H. 1954. Hydrography of the Dutch Wadden Sea. Arch. Néerl. Zool., 10:405-511. sedimentation, pages 123-186. Wiley, Chichester. 
638

639

640

641

642

643

644

645

646

647

648

649

650

651

652

653

654

655

656

657

658

659

660

661

662

663

664

665

666

Postma, H. 1981. Exchange of materials between the North Sea and the Wadden Sea. Mar. Geol., 40:199-213. http://dx.doi.org/10.1016/0025-3227(81)90050-5

Postma, H. 1982. Hydrography of the Wadden Sea : Movements and properties of water and particulate matter : final report on "Hydrography" of the Wadden Sea Working Group. Balkema A. A., Rotterdam.

Postma, H. 1984. Introduction to the symposium on organic matter in the Wadden Sea. Neth. Inst. Sea Res. Spec. Publ. Ser., 10:15-22.

Prastka, K., Sanders, R. and Jickells, T. 1998. Has the role of estuaries as sources or sinks of dissolved inorganic phosphorus changed over time? Results of a K d study Mar. Pollut. Bull., 36:718-728. http://dx.doi.org/10.1016/S0025-326X(98)00052-6

Prins, T. C., Desmit, X., and Baretta-Bekker, J. G. 2012. Phytoplankton composition in Dutch coastal waters responds to changes in riverine nutrient loads. J. Sea Res., 73:49-62.

http://dx.doi.org/10.1016/i.seares.2012.06.009

Rendell, A. R., Ottley, C. J., Jickells, T. D. and Harrison, R. M.1993. The atmospheric input of nitrogen species to the North Sea. Tellus B, 45:53-63. http://dx.doi.org/10.3402/tellusb.v45i1.15579

Ridderinkhof, H., Zimmerman, J. T. F., and Philippart, M. E. 1990. Tidal exchange between the North Sea and Dutch Wadden Sea and mixing time scales of the tidal basins. Neth. J. Sea Res., 25:331-350. http://dx.doi.org/10.1016/0077-7579(90)90042-F

Rosenberg, R. 1985. Eutrophication - the future marine coastal nuisance? Mar. Pollut. Bull., 16:227231.

Scavia, D. and Bricker, S. B. 2006. Nitrogen Cycling in the Americas: Natural and Anthropogenic Influences and Controls, In: Coastal eutrophication assessment in the United States, p187-208. Springer, Dordrecht.

Søndergaard, M., Bjerring, R., and Jeppesen, E. 2013. Persistent internal phosphorus loading during summer in shallow eutrophic lakes. Hydrobio, 710:95-107. http://dx.doi.org/10.1007/s10750-012$\underline{1091-3}$

Tappin, A. D. 2002. An examination of the fluxes of nitrogen and phosphorus in temperate and tropical estuaries: current estimates and uncertainties. Estuarine Coastal Shelf Sci., 55:885-901. http://dx.doi.org/10.1006/ecss.2002.1034 
667

668

669

670

671

672

673

674

675

676

677

678

679

680

681

682

683

684

685

686

687

688

689

690

691

692

693

694

695

Tiessen, M., Nauw, J., Ruardij, P., Gerkema, T. 2012. Numerical modeling of physical processes in the North Sea and Wadden Sea with GETM/GOTM, in: Kranenburg, W.M. et al. Jubilee Conference Proceedings NCK-days 2012 : crossing borders in coastal research. pp. 197-200. http://dx.doi.org/10.3990/2.197

van Aken, H. M. 2008a. Variability of the salinity in the western Wadden Sea on tidal to centennial time scales. J. Sea Res., 59:121-132. http://dx.doi.org/10.1016/i.seares.2007.11.001

van Aken, H. M. 2008b. Variability of the water temperature in the western Wadden Sea on tidal to centennial time scales. J. Sea Res., 60:227-234. http://dx.doi.org/10.1016/j.seares.2008.09.001

van Bennekom, A. J. and Wetsteijn, F. J. 1990. The winter distribution of nutrients in the Southern Bight of the North Sea (1961-1978) and in the estuaries of the Scheldt and the Rhine/Meuse. Neth. J. Sea Res., 25:75-87. http://dx.doi.org/10.1016/0077-7579(90)90010-E

van den Hurk, B., Tank, A. K., Lenderink, G., van Oldenborgh, G. J., Kastman, C., van den Brink, H., Keller, F., Bessembinder, J., Burgers, G., Komen, G. J., et al. 2006. KNMI climate change scenarios 2006 for the Netherlands. KNMI De Bilt.

van Meerendonk, J. H., Janssen, G. M., and Frederiks, B. 1988. De aanvoer van voedingsstoffen en microverontreinigingen naar de Waddenzee en Eems-Dollard. Rijkswaterstaat Report (nr. GWWS 88.002). Rijkswaterstaat, Haren.

van Raaphorst, W. and de Jonge, V. N. 2004. Reconstruction of the total N and P inputs from the IJsselmeer into the western Wadden Sea between 1935-1998. J. Sea Res., 51:109-131.

http://dx.doi.org/10.1016/j.seares.2003.07.002

van Raaphorst, W., de Jonge, V. N., Dijkhuizen, D., and Frederiks, B. 2000. Natural background concentrations of phosphorus and nitrogen in the Dutch Wadden Sea. Technical report, Rijkswaterstaat, RIKZ.

van Raaphorst, W. and Kloosterhuis, H. T. 1994. Phosphate sorption in superficial intertidal sediments. Mar. Chem., 48:1-16. http://dx.doi.org/10.1016/0304-4203(94)90058-2

van Raaphorst, W., Philippart, C. J. M., Smit, J. P. C., Dijkstra, F. J., and Malschaert, J. F. P. 1998.

Distribution of suspended particulate matter in the North Sea as inferred from NOAA/AVHRR reflectance images and in situ observations. J. Sea Res., 39:197 - 215.

http://dx.doi.org/10.1016/S1385-1101(98)00006-9 
696 van Raaphorst, W. and van der Veer, H. W. 1990. The phosphorus budget of the Marsdiep tidal basin

697 (Dutch Wadden Sea) in the period 1950-1985: importance of the exchange with the North Sea.

698 Hydrobio., 195:21-38. http://dx.doi.org/10.1007/BF00026811

699 Vermaat, J. E., McQuatters-Gollop, A., Eleveld, M. A., and Gilbert, A. J. 2008. Past, present and future 700 nutrient loads of the North Sea: Causes and consequences. Estuarine Coastal Shelf Sci., 80:53-59.

701 http://dx.doi.org/10.1016/i.ecss.2008.07.005

702 Visser, M., De Ruijter, W. P. M., and Postma, L. 1991. The distribution of suspended matter in the 703 Dutch coastal zone. Neth. J. Sea Res., 27:127-143. http://dx.doi.org/10.1016/0077-7579(91)90006$704 \underline{M}$

705 
Table 1: Main characteristics and water mass flows of the western Wadden Sea as based on the hydrodynamical model by (Ridderinkhof et al., 1990) and data on freshwater inputs between 1976 and 2012 (456 monthly averages) supplied by the Dutch Ministry of Transport

\begin{tabular}{lrrl}
\hline \hline Characteristics & Symbol & Value & Unit \\
\hline Volume & & $4.66 \times 10^{9}$ & $\mathrm{~m}^{3}$ \\
\hline Surface area & & $1.41 \times 10^{9}$ & $\mathrm{~m}^{2}$ \\
\hline Average depth & 3.3 & $\mathrm{~m}$ \\
\hline Tidal exchange & $3.60 \times 10^{7}$ & $\mathrm{~m}^{3}$ tide $^{-1}$ \\
\hline Tidal frequency & & 1.92 & tides day $^{-1}$ \\
\hline Residence time & & 9 & days $^{-}$ \\
\hline Freshwater discharges from Lake IJssel & $\mathrm{Q}_{\mathrm{d}}$ & $295 \pm 151$ & $\mathrm{~m}^{3} \mathrm{~s}^{-1}$ \\
\hline & $\mathrm{Q}_{c}$ & $210 \pm 131$ & $\mathrm{~m}^{3} \mathrm{~s}^{-1}$ \\
\hline Advective transport via Vlie inlet & $\mathrm{Q}_{2}$ & $696 \pm 65$ & $\mathrm{~m}^{3} \mathrm{~s}^{-1}$ \\
\hline Dispersive transport (tidal exchange) & $\mathrm{K}_{1}$ & 3556 & $\mathrm{~m}^{3} \mathrm{~s}^{-1}$ \\
\hline Advective transport to North Sea & $\mathrm{Q}_{1}$ & $1199 \pm 210$ & $\mathrm{~m}^{3} \mathrm{~s}^{-1}$ \\
\hline
\end{tabular}

711 total phosphorus and nitrogen concentrations, respectively, small letters a to $f$ to the respective stations used in the budgets (see Fig. 1).

\begin{tabular}{|c|c|c|c|c|c|c|c|}
\hline Nutrient & Fluxes & Name & Function & $\begin{array}{r}1976- \\
1977\end{array}$ & $\begin{array}{r}1978- \\
1987\end{array}$ & $\begin{array}{r}1988- \\
1993\end{array}$ & $\begin{array}{r}1994- \\
2012\end{array}$ \\
\hline \multirow[t]{5}{*}{ Phosphorus } & Input & Outflow Lake IJssel & $Q d \times P d+Q e \times P e$ & 0.15 & 0.24 & 0.16 & 0.15 \\
\hline & Input & Advective transport Vlie & $Q 2 \times P C$ & 0.17 & 0.15 & 0.12 & 0.08 \\
\hline & Output & Advective transport Marsdiep & $Q 1 \times P b$ & -0.32 & -0.36 & -0.25 & -0.15 \\
\hline & Output & Exchange North Sea & $K 1 \times(P a-P b)$ & -0.22 & -0.09 & -0.04 & -0.03 \\
\hline & Residual & Residual1 & FTP, residual & 0.23 & 0.06 & 0.00 & -0.04 \\
\hline \multirow[t]{7}{*}{ Nitrogen } & Input & Outflow Lake IJssel & $Q d \times N d+Q e \times N e$ & 6.00 & 9.55 & 8.12 & 7.94 \\
\hline & Input & Atmosphere & Fatm & 0.19 & 0.19 & 0.19 & 0.19 \\
\hline & Input & Advective transport Vlie & $Q 2 \times N c$ & 4.56 & 2.82 & 2.37 & 1.97 \\
\hline & Output & Advective transport Marsdiep & $Q 1 \times N b$ & -7.68 & -6.18 & -4.71 & -4.18 \\
\hline & Output & Exchange North Sea & $K 1 \times(N a-N b)$ & -10.91 & -4.65 & -2.03 & -2.25 \\
\hline & Residual & Residual1 & FTN, residual1 & 3.91 & 1.08 & 0.21 & -0.50 \\
\hline & Residual & Residual2 & FTN, residual2 & 3.93 & -2.81 & -4.13 & -3.18 \\
\hline
\end{tabular}




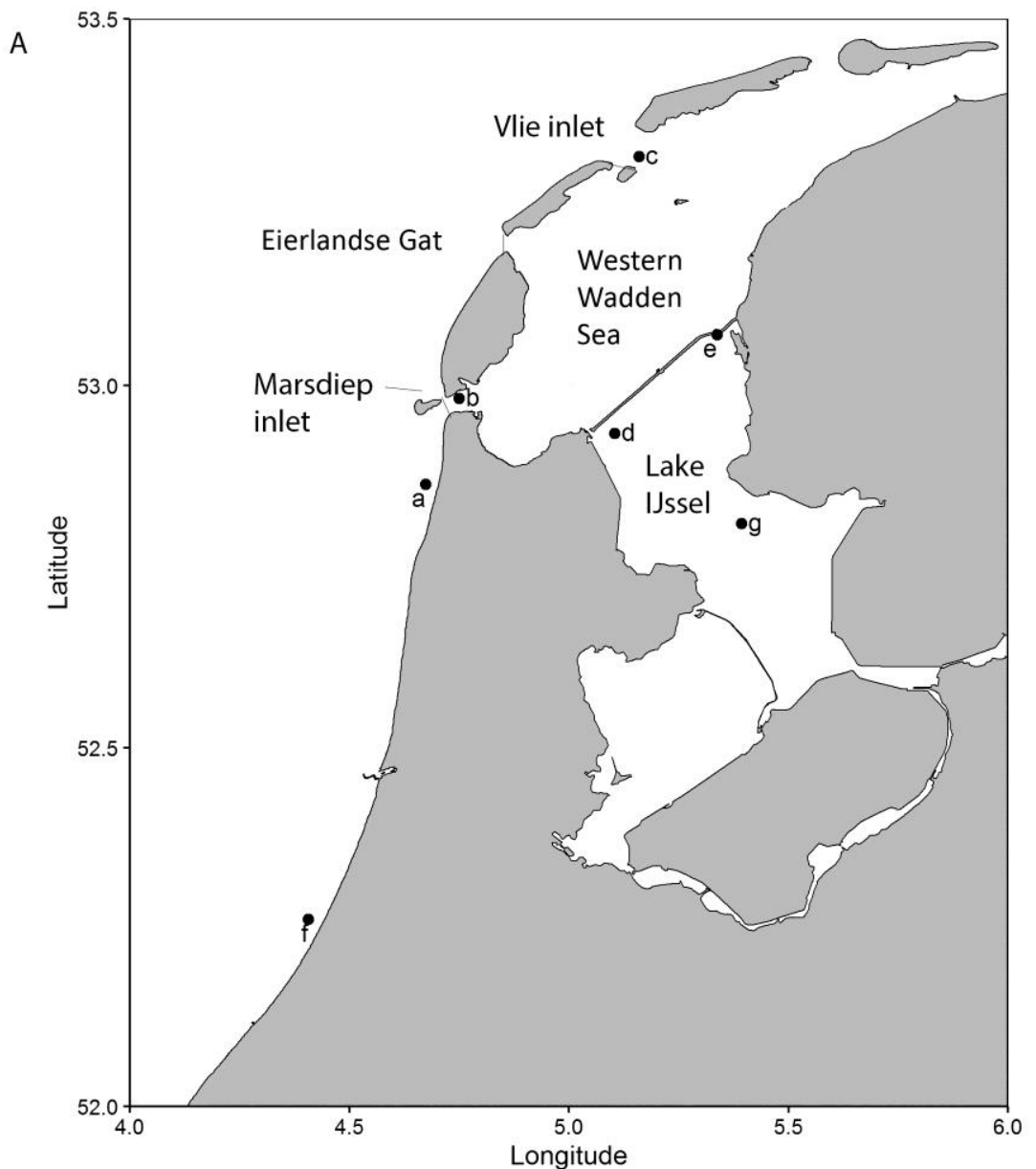

B

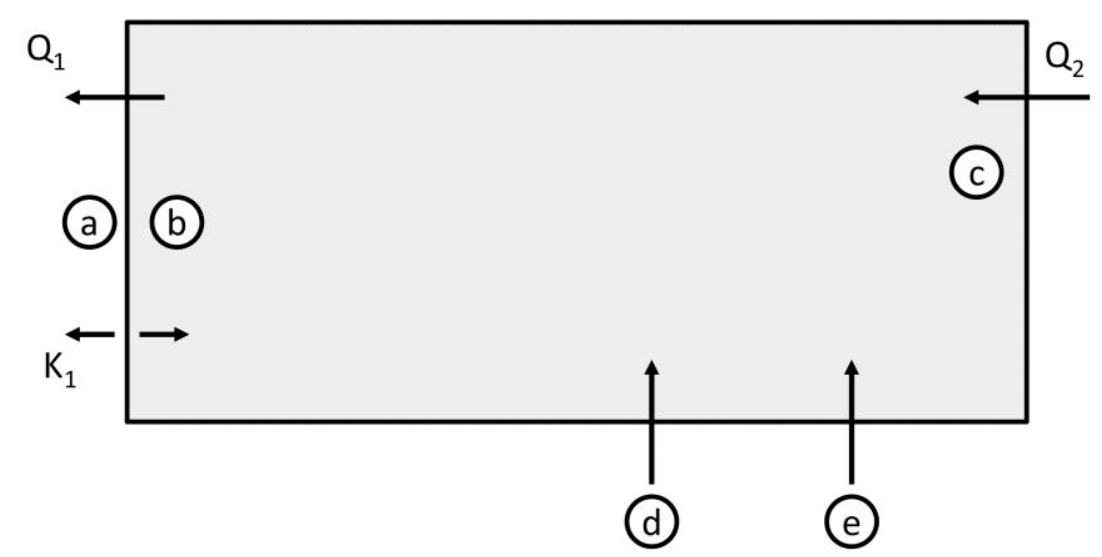

717 Figure 1: The study area with locations of the sampling stations in the North Sea (Station a, Callantsoog) and Noordwijk

718 (Station $\mathrm{f}$ ), the western Wadden Sea (Station b, Marsdiep; Station c, Vliestroom), and near the sluices in the dam that 719 closes off the man-made freshwater Lake IJssel from the Wadden Sea (Station d, Den Oever; Station e, Kornwerderzand 720 and Station g, Vrouwezand). (A) Geographical map of the study area. (B) One-compartment representation of the western 721 Wadden Sea. Solid arrows represent tidally averaged advective water transport $\left(Q_{1}, Q_{2}\right)$ and bimonthly averaged major 722 freshwater inputs $\left(Q_{d}, Q_{e}\right)$; the dashed arrow $\left(K_{1}\right)$ represents the dispersive exchange with the North Sea (Ridderinkhof et al., 1990). 
A, Import from Lake IJssel

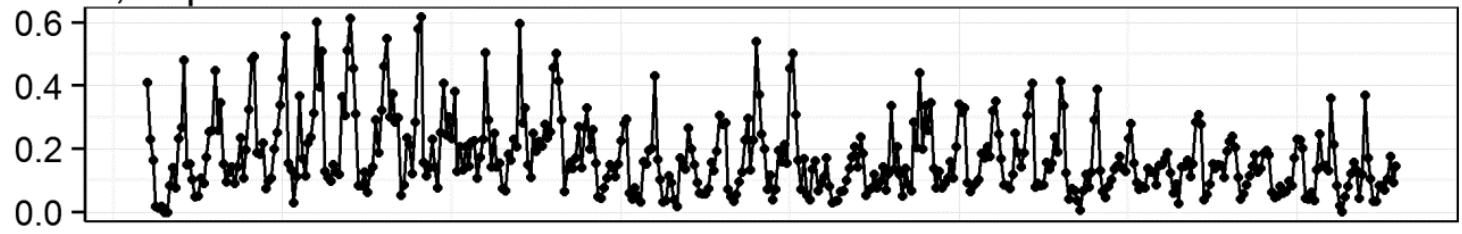

B, Advective transport at Vlie
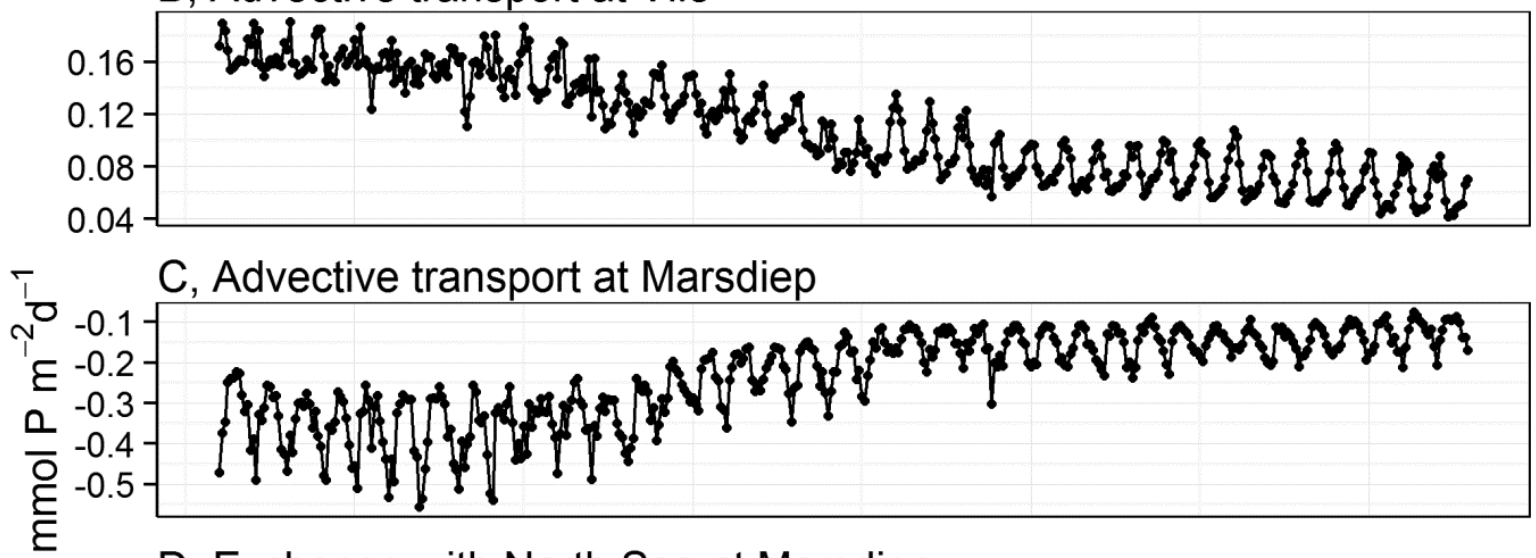

D, Exchange with North Sea at Marsdiep

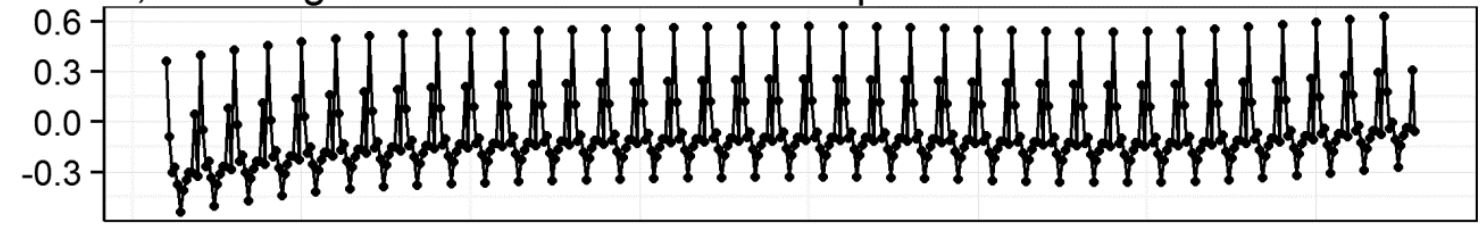

E, Closing residual

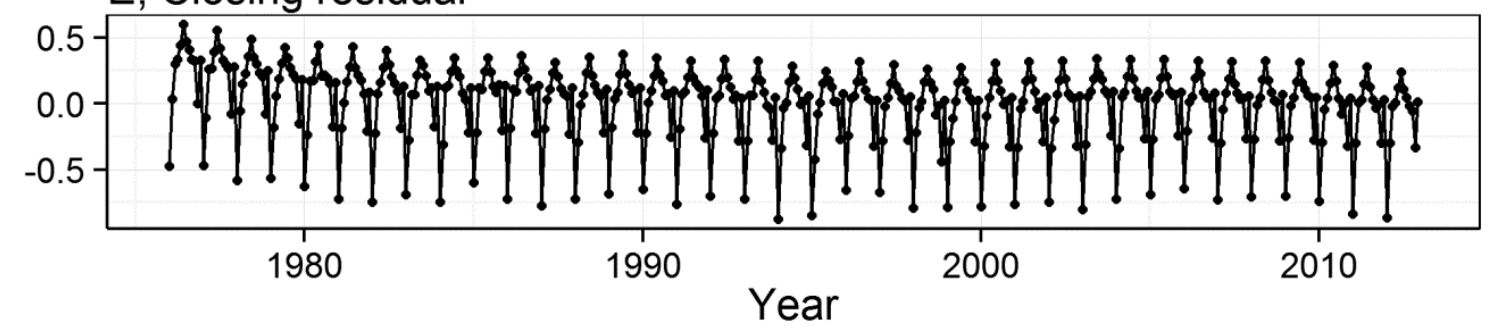

Figure 2: Time series of monthly total phosphorus budget terms $\left(\mathrm{mmol} \mathrm{P} \mathrm{m}^{-2} \mathrm{~d}^{-1}\right)$ in the western Wadden Sea with points being drawn at the first of the month as a representative for the whole month, A) Import from Lake IJssel, B) advective transport at Vlie tidal inlet, C) advective transport at the Marsdiep tidal inlet, D) exchange with North Sea at the Marsdiep tidal inlet, E) closing residual. Positive values indicate input into the tidal basins. Note the difference in the scale of the $y-$ 


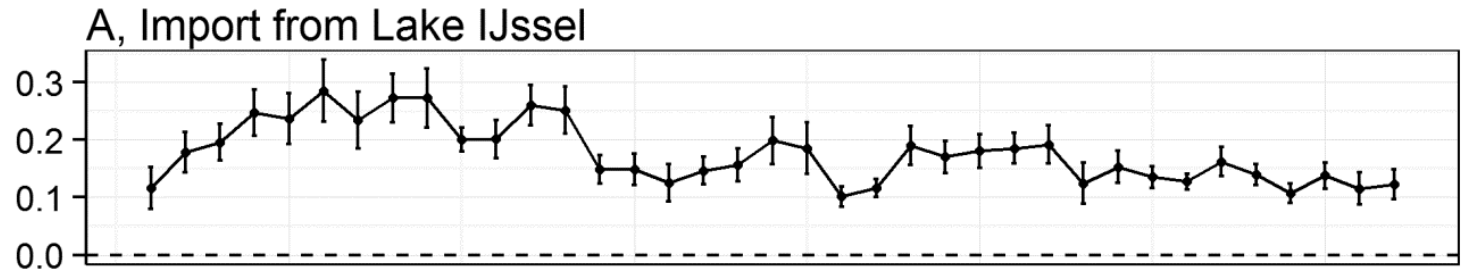

B, Advective transport at Vlie
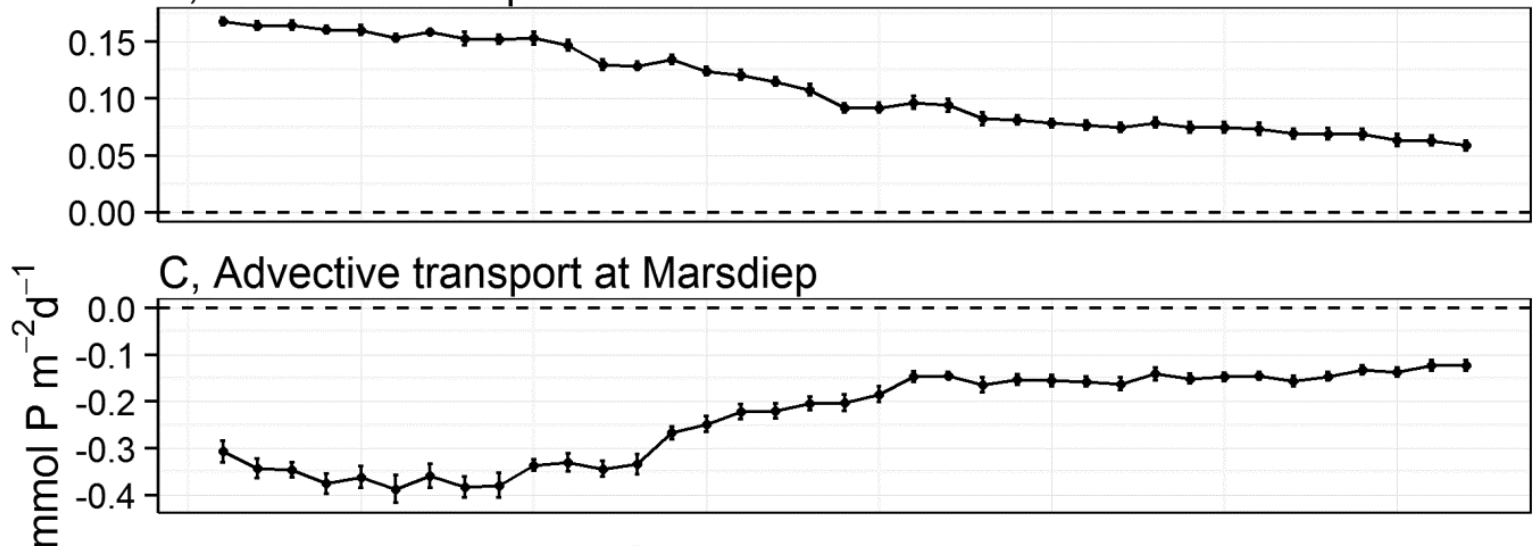

D, Exchange with North Sea at Marsdiep
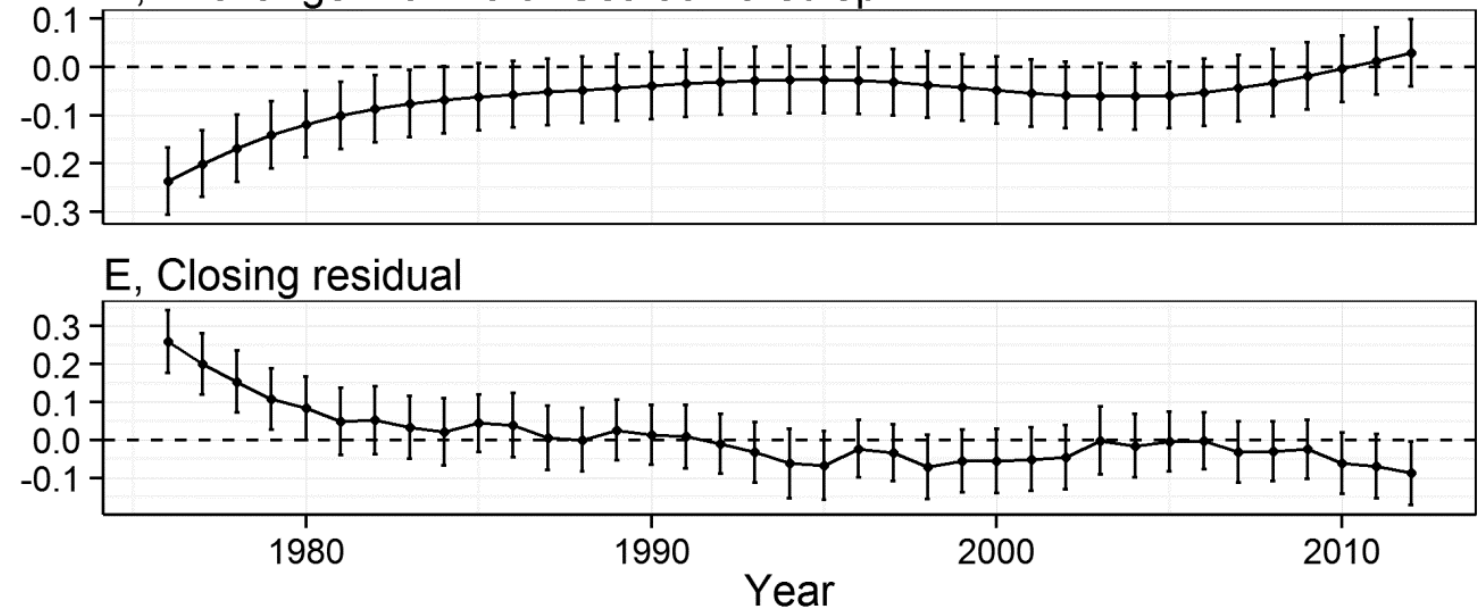

Figure 3: Time series of annual total phosphorus (TP) budget terms $\left(\mathrm{mmol} \mathrm{P} \mathrm{m}^{-2} \mathrm{~d}^{-1}\right)$ in the western Wadden Sea (means \pm SD) with points being drawn at the first of the year as a representative for the whole year, A) Import from Lake IJssel, B) advective transport at Vlie tidal inlet, C) advective transport at the Marsdiep tidal inlet, D) exchange with North Sea at the Marsdiep tidal inlet, E) closing residual. Positive values indicate net import into the tidal basins. Note the differences between the scales of the $y$-axes. 
A, Import from Lake IJssel

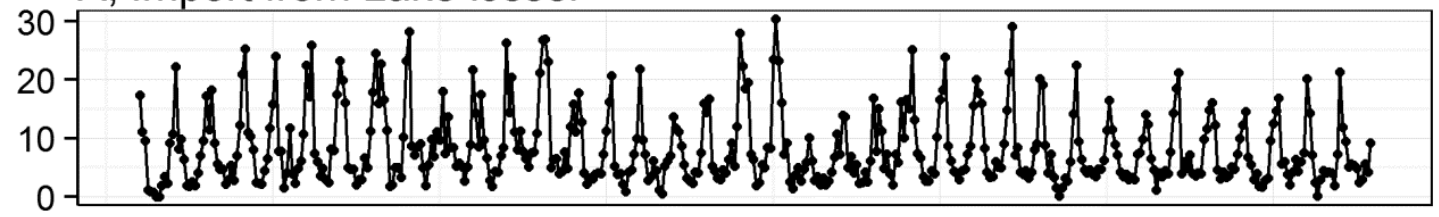

B, Advective transport at Vlie

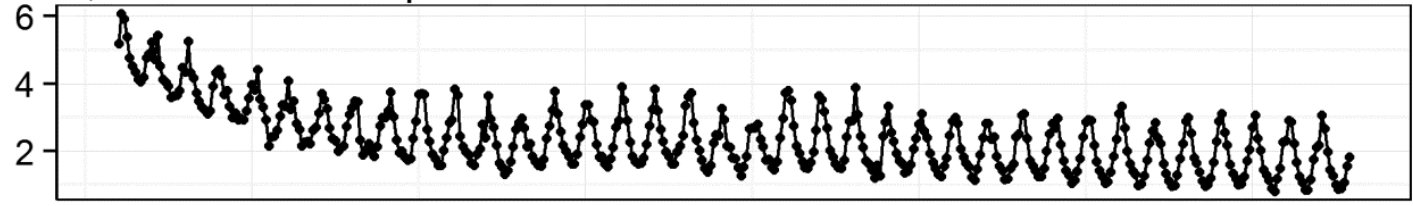

C, Advective transport at Marsdiep
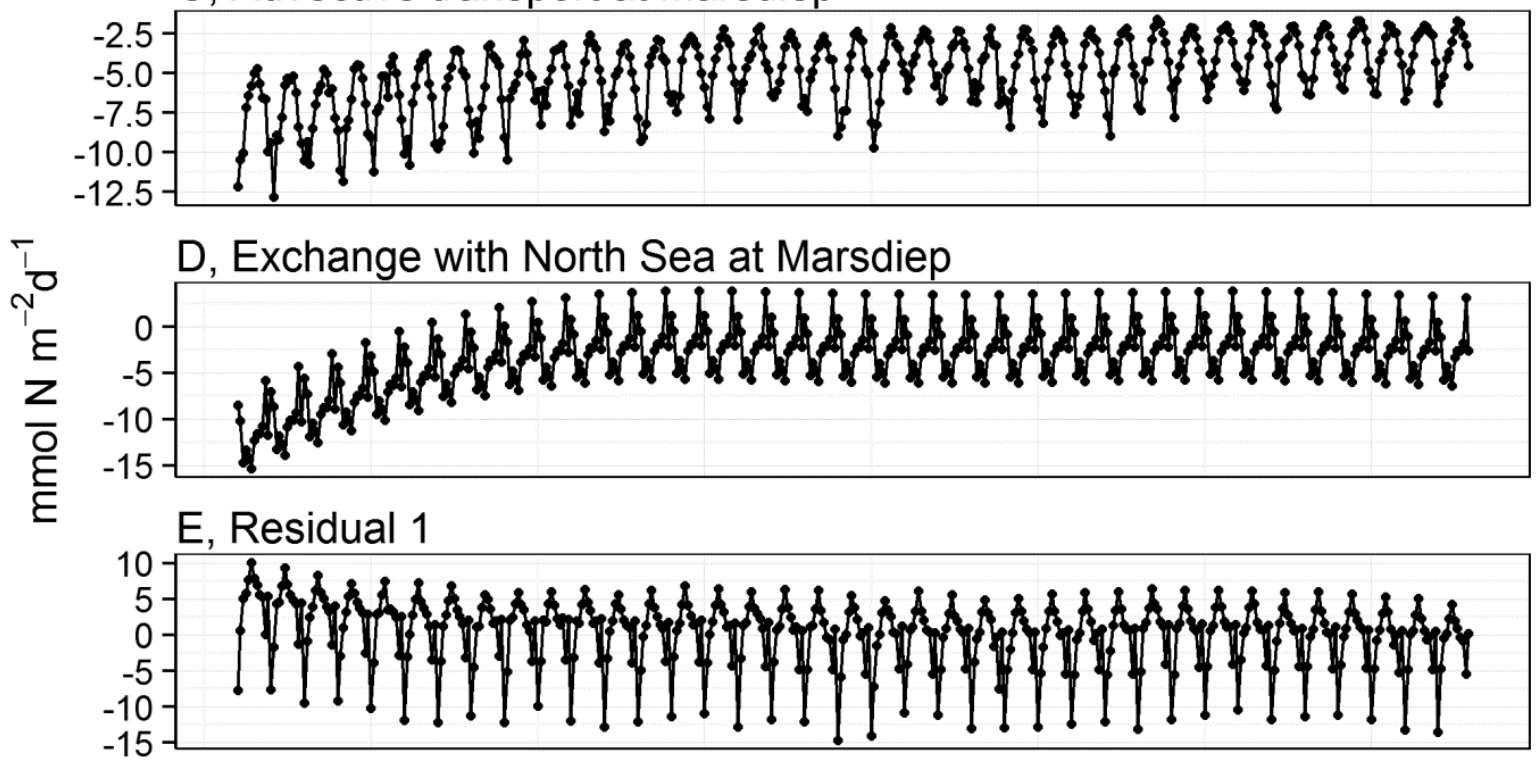

F, Residual 2

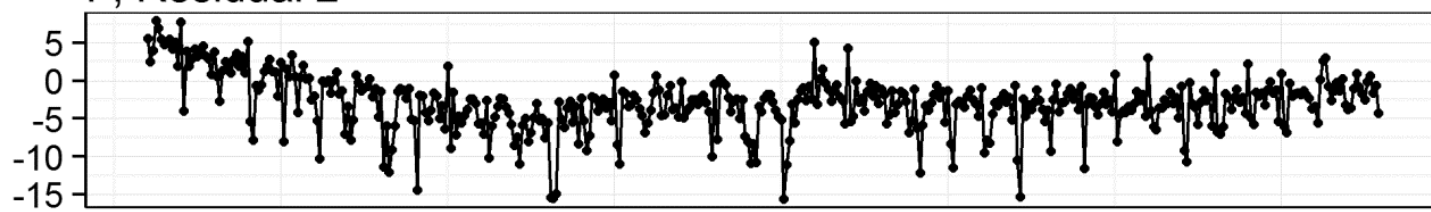

G, Total Residual

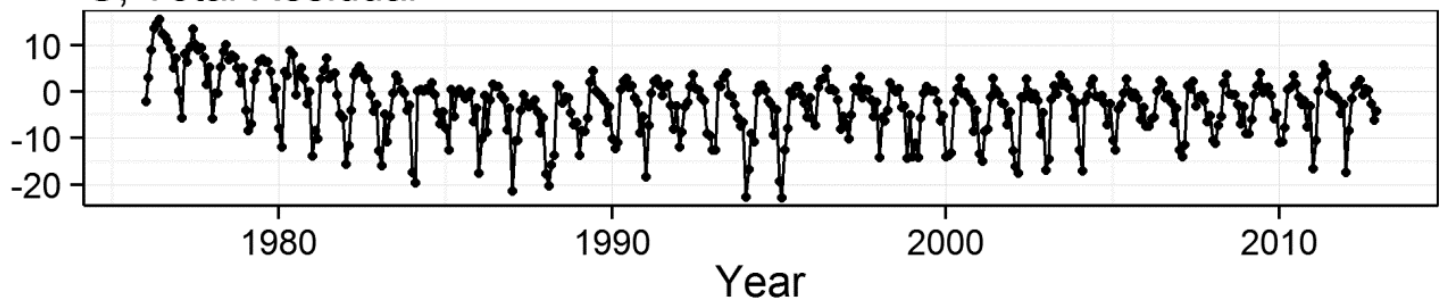

Figure 4: Time series of monthly total nitrogen $\left(\mathrm{mmol} \mathrm{N} \mathrm{m}^{-2} \mathrm{~d}^{-1}\right)$ budget terms in the western Wadden Sea with points being drawn at the first of the month as a representative for the whole month, A) Import from Lake IJssel, B) advective transport at Vlie tidal inlet, C) advective transport at the Marsdiep, D) tidally driven exchange with North Sea at the Marsdiep tidal inlet, E) residual 1 derived from residual of $\mathrm{P}$ budget, F) residual 2, closing residual, G) Total residual. 
A, Import from Lake IJssel

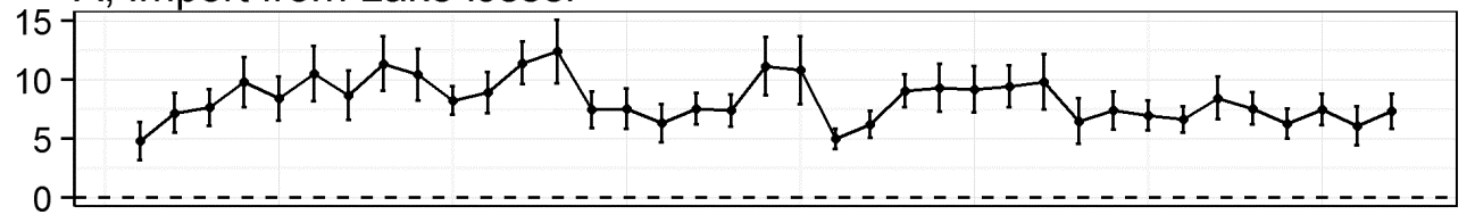

B, Advective transport at Vlie

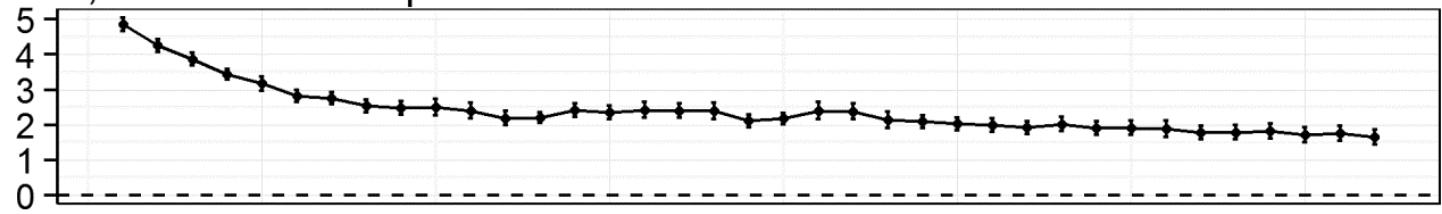

C, Advective transport at Marsdiep

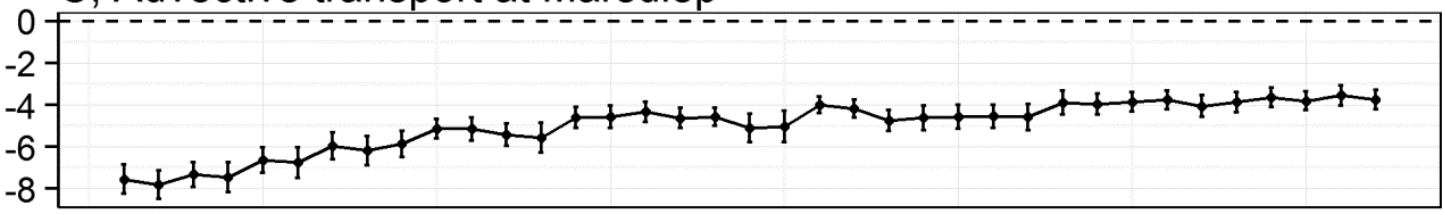

D, Exchange with North Sea at Marsdiep
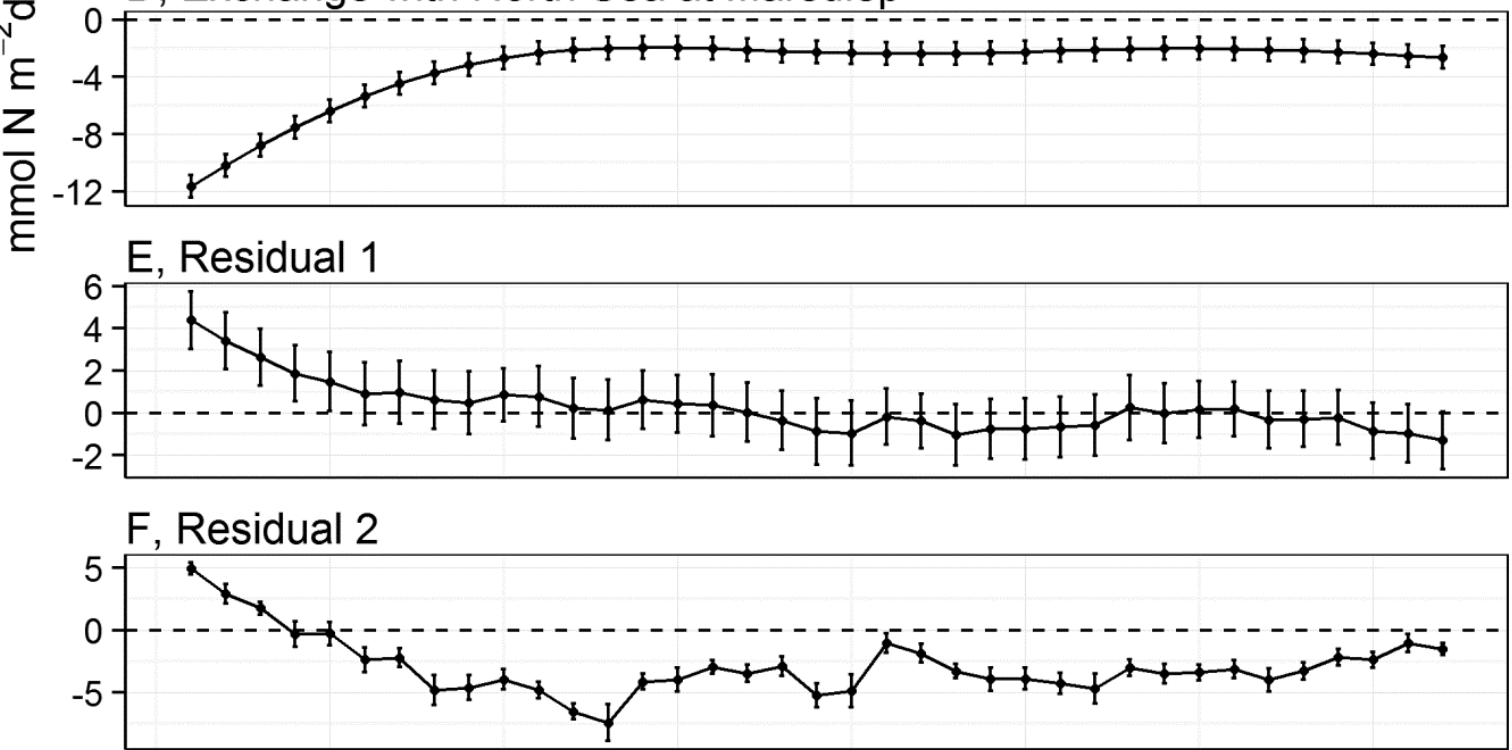

G, Total Residual

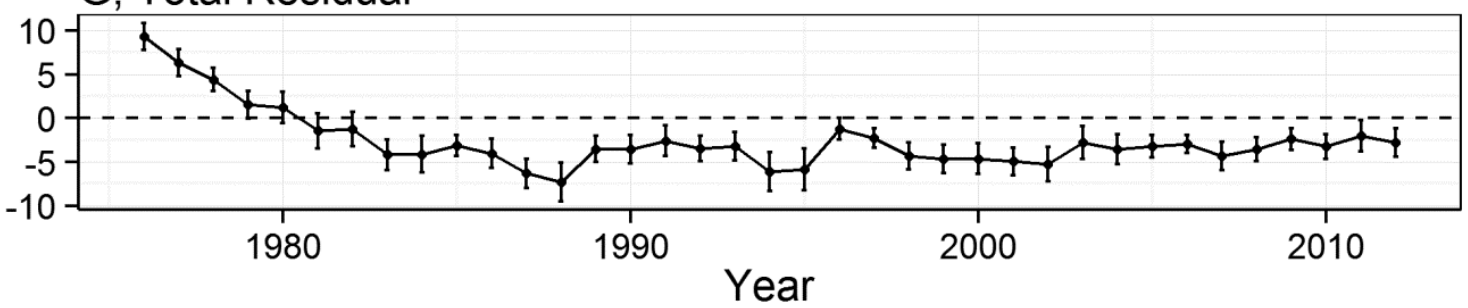

Figure 5: Time series of annual total nitrogen (TN) budget terms $\left(\mathrm{mmol} \mathrm{N} \mathrm{m}^{-2} \mathrm{~d}^{-1}\right)$ in the western Wadden Sea (means \pm SD) with points being drawn at the first of the year as a representative for the whole year, A) Import from Lake IJssel, B) advective transport at Vlie tidal inlet, C) advective transport at the Marsdiep tidal inlet, D) exchange with North Sea at the Marsdiep tidal inlet, E) residual 1 derived from the residual of the P budget, F) residual 2, closing residual, G) Total residual. 

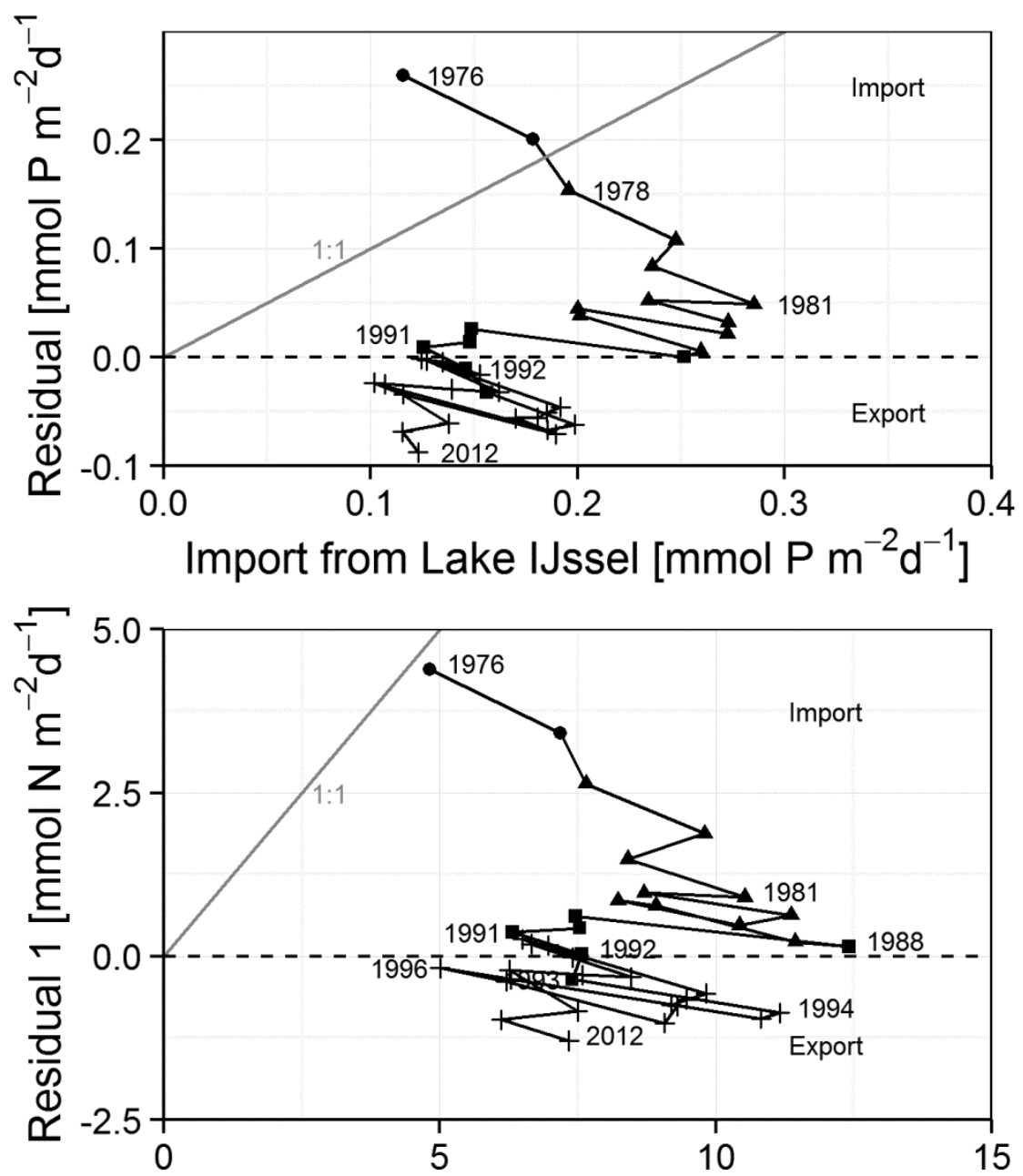

\section{Period}
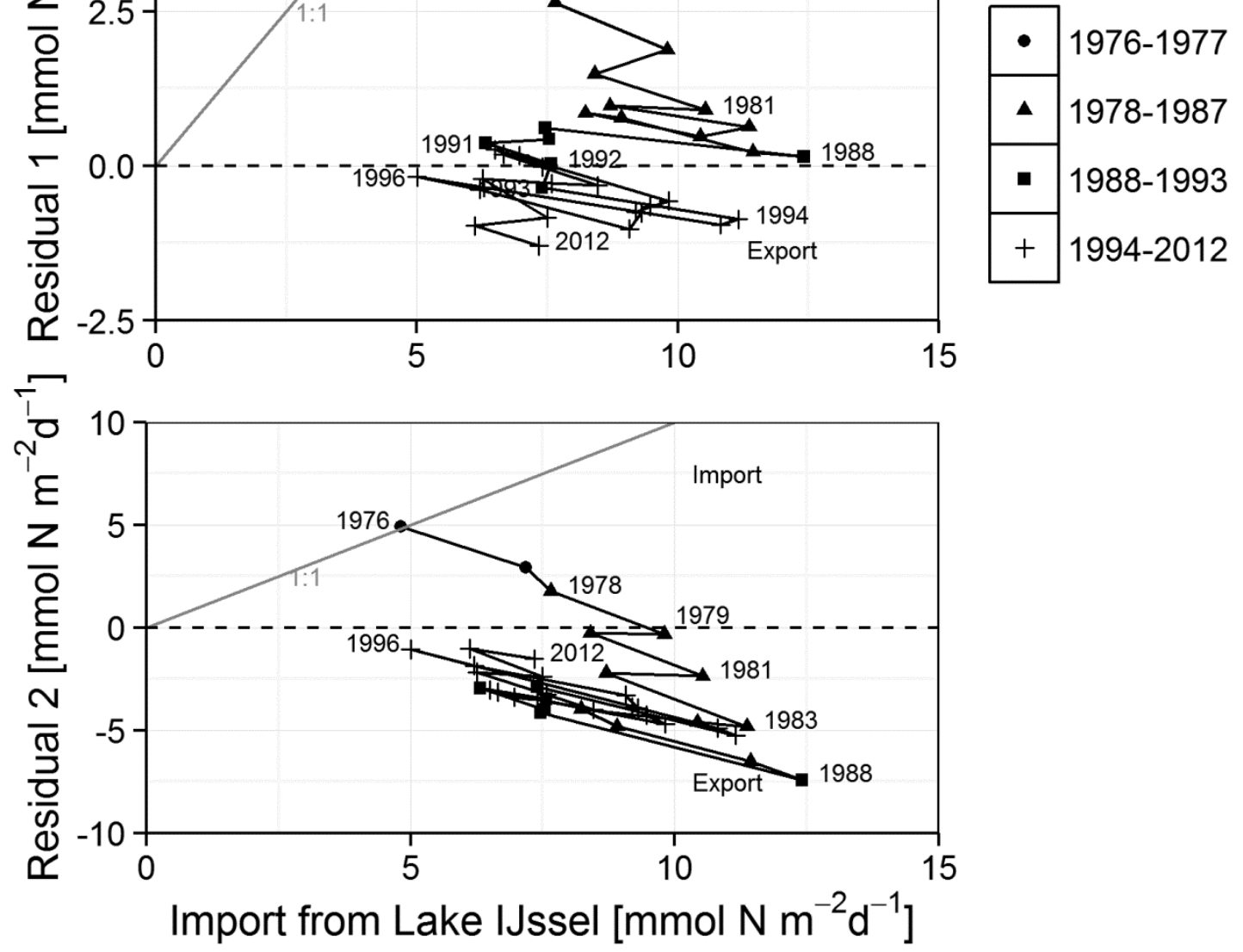

755 Figure 6: Closing residuals versus import from Lake IJssel. Residual of phosphorus budget vs import of P from Lake IJssel 756 (A). Residual 1 of nitrogen budget (B) and Residual 2 of nitrogen budget (C) vs import of $\mathrm{N}$ from Lake IJssel in different 757 periods; grey line represents the 1:1 line. Note the difference in the scale of the axes. 


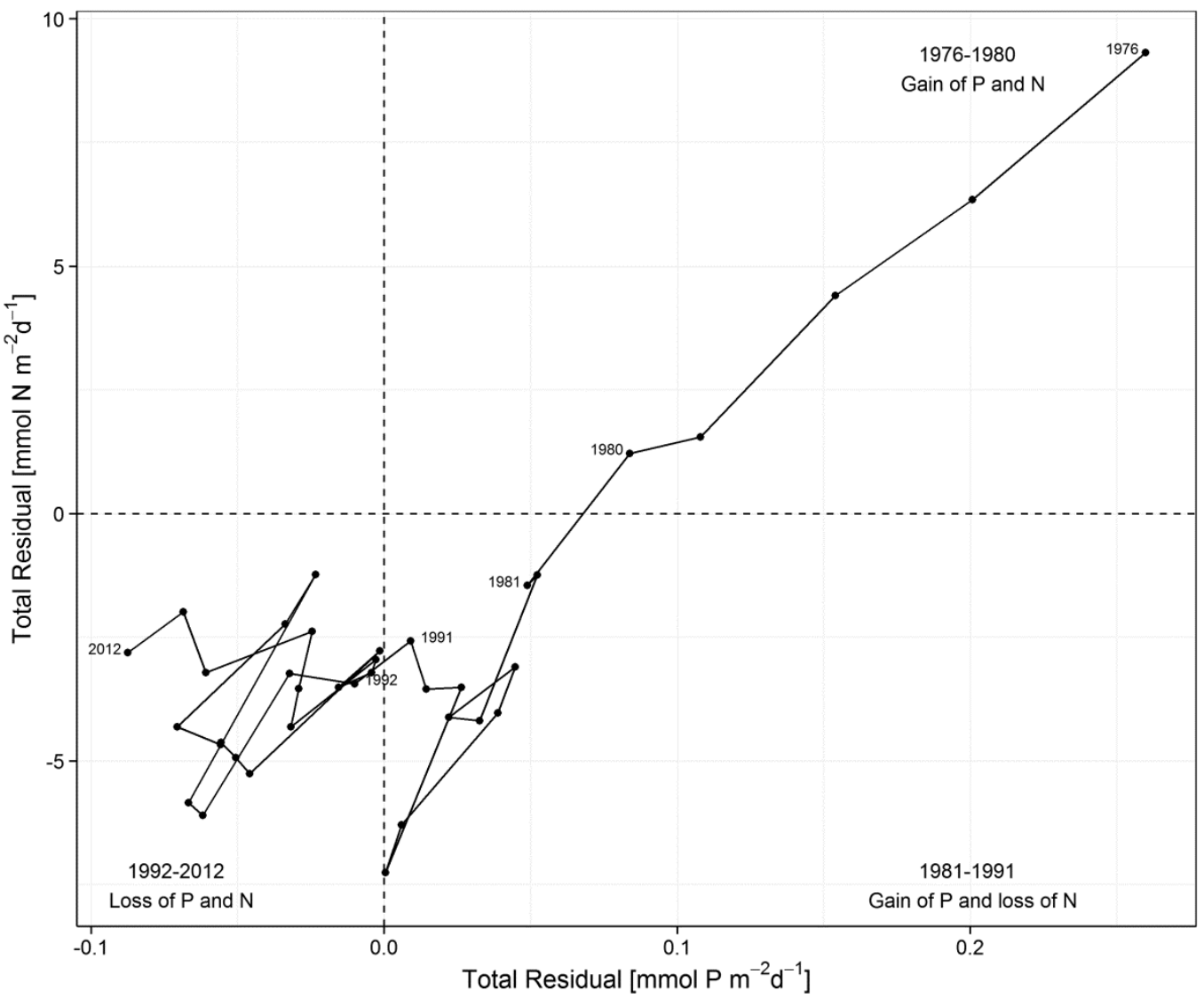

Figure 7: Residual of phosphorus budget vs total residuals of nitrogen budget over study period.
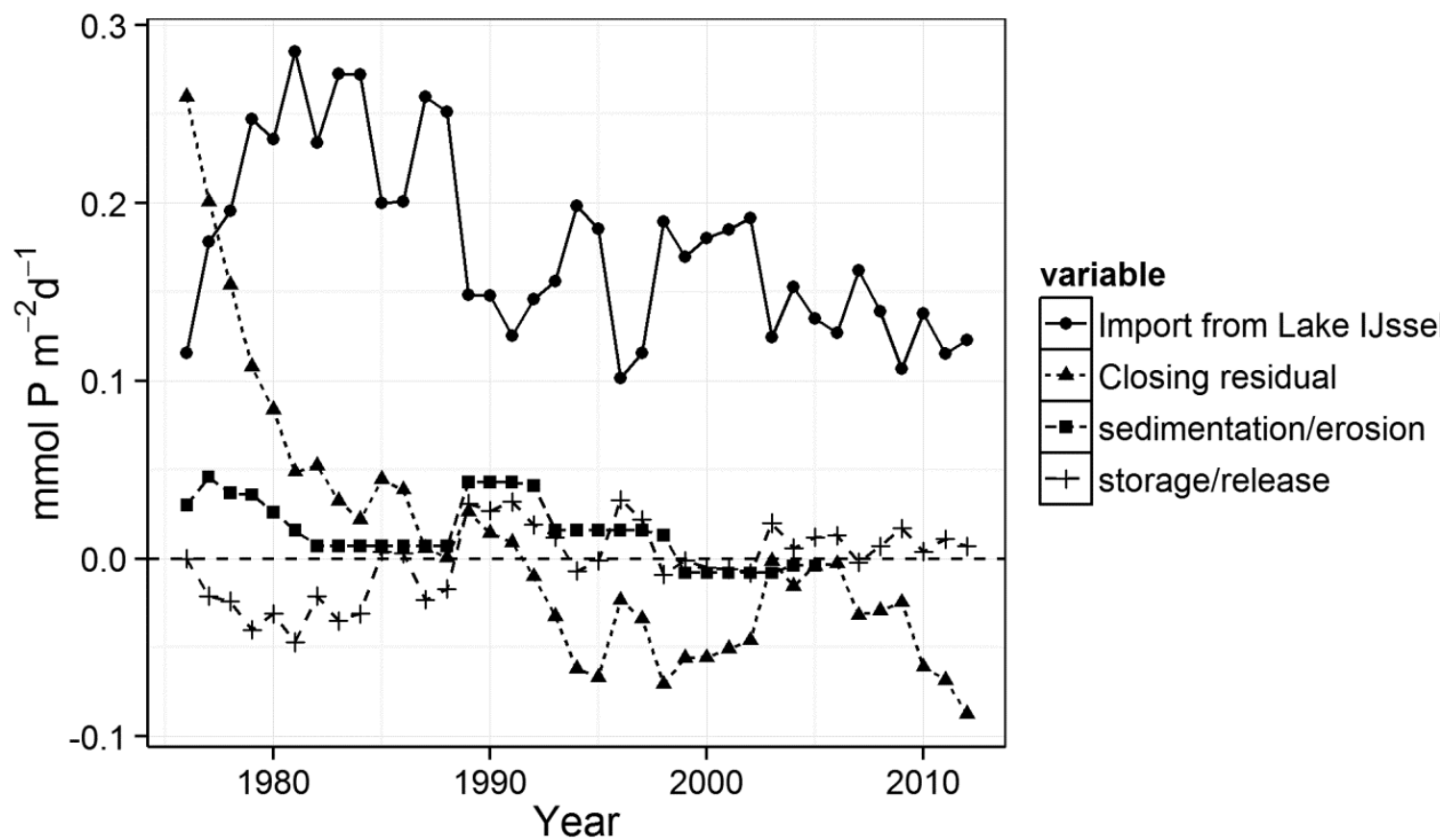

Figure 8: Time series of import of phosphorus from Lake IJssel (circles), the residual of the P budget (triangles), the estimated phosphorus transported by sediment (squares) and the estimated amount of phosphorus exchanged with the sediment (cross) in the western Wadden Sea. 